\title{
Hypoxia-Driven Effects in Cancer: Characterization, Mechanisms, and Therapeutic Implications
}

\author{
Rachel Shi, Chengheng Liao (1) and Qing Zhang * \\ Department of Pathology, University of Texas Southwestern Medical Center, Dallas, TX 75390, USA; \\ rachel.shi@utsouthwestern.edu (R.S.); chengheng.liao@utsouthwestern.edu (C.L.) \\ * Correspondence: Qing.Zhang@UTSouthwestern.edu; Tel.: +1-214-645-4671
}

Citation: Shi, R.; Liao, C.; Zhang, Q. Hypoxia-Driven Effects in Cancer: Characterization, Mechanisms, and Therapeutic Implications. Cells 2021, 10, 678. https://doi.org/10.3390/ cells10030678

Academic Editor: Daniele M. Gilkes

Received: 2 March 2021

Accepted: 17 March 2021

Published: 19 March 2021

Publisher's Note: MDPI stays neutral with regard to jurisdictional claims in published maps and institutional affiliations.

Copyright: (c) 2021 by the authors. Licensee MDPI, Basel, Switzerland. This article is an open access article distributed under the terms and conditions of the Creative Commons Attribution (CC BY) license (https:// creativecommons.org/licenses/by/ $4.0 /)$.

\begin{abstract}
Hypoxia, a common feature of solid tumors, greatly hinders the efficacy of conventional cancer treatments such as chemo-, radio-, and immunotherapy. The depletion of oxygen in proliferating and advanced tumors causes an array of genetic, transcriptional, and metabolic adaptations that promote survival, metastasis, and a clinically malignant phenotype. At the nexus of these interconnected pathways are hypoxia-inducible factors (HIFs) which orchestrate transcriptional responses under hypoxia. The following review summarizes current literature regarding effects of hypoxia on DNA repair, metastasis, epithelial-to-mesenchymal transition, the cancer stem cell phenotype, and therapy resistance. We also discuss mechanisms and pathways, such as HIF signaling, mitochondrial dynamics, exosomes, and the unfolded protein response, that contribute to hypoxia-induced phenotypic changes. Finally, novel therapeutics that target the hypoxic tumor microenvironment or interfere with hypoxia-induced pathways are reviewed.
\end{abstract}

Keywords: hypoxia; metastasis; hypoxia-inducible factors; chemoresistance

\section{Introduction}

Understanding the mechanisms by which cells sense oxygen and maintain oxygen homeostasis is of pivotal importance for science and medicine. Only in recent decades have breakthrough discoveries of mechanisms for eukaryotic oxygen sensing been made. In response to changing oxygen concentrations, cells maintain intracellular oxygen homeostasis in a myriad of ways such as mRNA reprogramming, metabolic alterations, reoxygenation via angiogenesis, and avoidance of toxic anaerobic by-products [1]. Oxygen levels can affect the stability of enzymes and other proteins which in turn affect transcriptional responses. The discovery of oxygen-sensing mechanisms has not only generated life-saving therapeutic advancements for cancers, cardiovascular conditions, and renal diseases but also earned Drs. Gregg Semenza, William Kaelin Jr., and Peter Ratcliffe the 2019 Nobel Prize in Physiology or Medicine [2].

Despite modest decreases in mortality rates over recent years, cancer continues to be a burdensome national health issue and the second leading cause of death in the U.S. [3]. Solid tumors in particular are associated with poor clinical prognosis because of systemic metastases and local resistance to anti-cancer therapies. Hypoxia, a condition in which oxygen levels are lower than normal physiological oxygenation of tissues $(4-9 \%)$, is a hallmark of solid tumors and an indicator of poor prognosis in many cancers including prostate, cervix, breast, head and neck cancers [4]. Hypoxia generally ranges from 1-2\% $\mathrm{O}_{2}$ but depends on the tumor size, stage, initial oxygenation level, and method of oxygen measurement $[5,6]$. Tumor physiology and distance to tumor microvessels can influence the extent of hypoxia; some areas can be anoxic ( $0 \%$ oxygen) or severely hypoxic (around $0.2 \%$ oxygen).

There are also different types of hypoxia; for instance, chronic or diffusion-limited hypoxia is defined by a continual state of hypoxia because of the inability of oxygen to diffuse to metabolically active cells. Cycling hypoxia (also known as intermittent or transient 
hypoxia) is characterized by cyclical fluctuations of acute hypoxia and reoxygenation [7]. Intra-tumoral acute hypoxia is typically induced by the temporary absence or restriction of blood supply [8]. Oxygen homeostasis is maintained in normal tissues through a balance of oxygen supply and demand, but in proliferating tumors, oxygen demand exceeds supply, such as through metabolic reprogramming. Consequently, chaotic angiogenic signaling leads to rapid, disorganized blood vessel formation, mediated by vascular endothelial growth factor (VEGF) [7].

Responses to hypoxia are predominantly mediated by HIFs, first identified in the 1990s [9,10]. In canonical HIF signaling, hypoxia leads to the stabilization of the labile protein HIF- $1 \alpha$ or HIF- $2 \alpha$ which complexes with HIF- $\beta$ (or ARNT), forming heterodimer HIF-1 or HIF-2 that binds to DNA at hypoxia-response elements (HREs) [11]. HIFs subsequently regulate the transcription of genes that affect cell growth, vascularization, metabolism, and oxygen consumption and delivery in a context-dependent manner [12]. The stability of the HIF- $\alpha$ subunits is determined by the hydroxylation of specific prolyl residues (by prolyl hydroxylases (PHDs) 1-3 or EglNs 2, 1, and 3, respectively). HIF- $\alpha$ can also be hydroxylated at an asparaginyl residue (by factor-inhibiting HIF (FIH)). The prolyl and asparaginyl hydroxylations require oxygen and increase the affinity of HIF- $\alpha$ for the von Hippel-Lindau (VHL) protein, a component of an E3 ubiquitin ligase [13]. Under normoxia, VHL polyubiquitinates HIF- $\alpha$ tagging it for $26 \mathrm{~s}$ proteasomal degradation [13], whereas under hypoxic conditions, the activity of prolyl hydroxylases is inhibited, and HIF- $\alpha$ is stabilized and able to form the HIF heterodimer which binds to DNA and incites a transcriptional response. There are three HIF isoforms, each with distinct functions, to be discussed in more detail in Section 3.1. Prolyl hydroxylases belong to a larger superfamily of enzymes known as 2-oxoglutarate-dependent dioxygenases (2OGDDs), many of which (e.g., PHDs, JmjC domain-containing enzymes, and ten eleven translocation (TET) enzymes) are oxygen-sensitive and have increasingly been researched in contexts of cancer [14,15].

Research on cancer hypoxia has spanned decades, driven by numerous research groups, and there have been inconsistencies in the in vitro experimental conditions of acute, chronic, and cycling hypoxia induced under [16]. For instance, acute hypoxia has been studied through exposing cells to continuous hypoxia from a few minutes to $72 \mathrm{~h}$ [16-18]. In addition, the in vitro experimental methods of acute and chronic hypoxia may not recapitulate in vivo complex hypoxic tumor conditions. In vitro and intra-tumoral hypoxia also result in distinct gene expression signatures [19], complicating extrapolations of results from hypoxic culture experiments to in vivo and clinical settings. Due to these discrepancies, there is no clear consensus on the biological consequences of chronic hypoxia, with one study reporting chronic hypoxic cells demonstrating higher invasiveness than cells exposed to acute hypoxia [20] and another reporting that chronic hypoxia leads to regressive changes [21]. These differences may be attributed to the usage of different cell lines and variable cell states at induction of hypoxia.

With these considerations in mind, connections between hypoxia and pathological indicators such as tumor proliferation, metastasis, invasion, and cancer stem cell-like phenotype continue to be illuminated in emerging research. The dynamic and heterogeneous distributions of hypoxia elicit unique metabolic signatures and transcriptional reprogramming in cells. Many resulting pathways contribute to cancer proliferation and therapeutically relevant phenotypes [7]. The following review will highlight current knowledge on the effects of hypoxia on mutagenesis, DNA repair mechanisms, metastasis, the stem cell phenotype, and resistance to therapies in the context of cancer. In addition, the hypoxia-mediated drivers of cancer malignancy including HIFs and the unfolded protein response (UPR) will be summarized, along with cancer therapeutics that target the oxygen-sensing pathways and cellular adaptations to hypoxia. 


\section{Effects of Hypoxia on Cancer Molecular and Cellular Characteristics}

\subsection{Mutagenesis and Impaired DNA Repair}

Hypoxia generally results in the necrosis of tissues distantly located from host blood vessels and the activation of various pathways that enable surviving cells to transform into malignant, proliferating, clinically relevant tumors [22]. Changes at the genetic level may underlie hypoxic cellular adaptation. A study in 1996 first implicated hypoxia as an environmental factor that is associated with genetic mutations in a tumorigenic cell line [23]. While hypoxia does not directly damage DNA, studies utilizing plasmid reporter systems have shown that hypoxia indirectly induces hypermutation, DNA strand breaks, oxidative base damage, and DNA over-replication (Figure 1) [24-26].

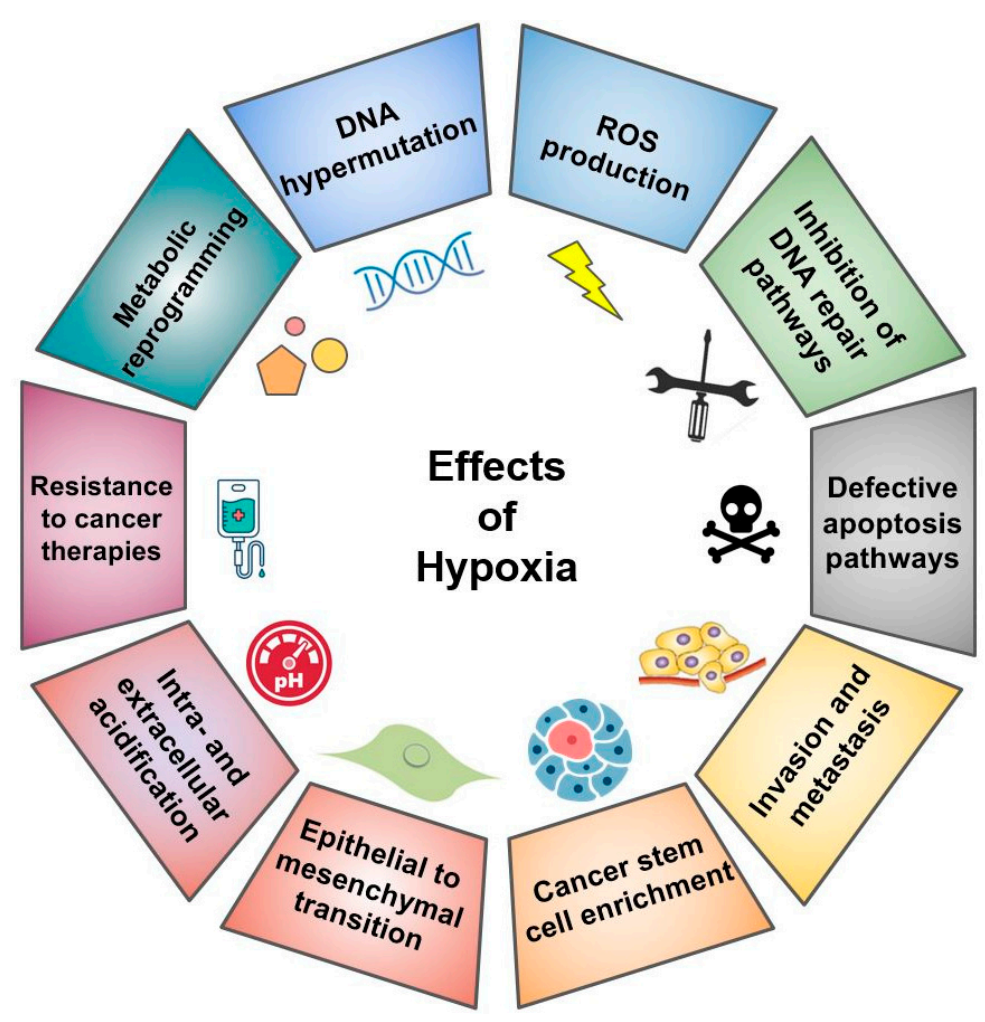

Figure 1. The spectrum of effects of hypoxia on cancer cells. Hypoxia affects cancer cell fate, genetics, metabolism, and clinicopathology. ROS: Reactive oxygen species. DNA: Deoxyribonucleic acid.

The DNA repair response and associated cell cycle and apoptosis signaling is mediated by three major enzymes, ataxia-telangiectasia-mutated kinase (ATM), ataxia telangiectasia and Rad3-related protein (ATR), and DNA-dependent protein kinase (DNA-PK), which belongs to the family of phosphoinositide 3-kinase-related kinases. Whereas ATM and DNAPK are activated by double-stranded breaks, ATR is activated by replication stress. Hypoxia has been found to promote HIF-1 $\alpha$ phosphorylation in an ATM-dependent manner and activate the mechanistic target of rapamycin (mTOR) pathway and subsequent survival and proliferation signals in pediatric solid tumors [27]. Hypoxia and ATM deficiency results in dysregulation of mTORC1, stabilization of p53, and activation of p53-mediated apoptosis [27]. In addition, hypoxia is linked with increased ATM activity and phosphorylation of its substrate Chk2, which causes G2 cell-cycle arrest and protection against apoptosis for colorectal carcinoma cell lines under acute and cycling hypoxia [28]. One consequence of hypoxia is the diminished current of electrons through the electron transport chain (ETC) and an increase in leaking electrons at the ETC, resulting in the production of ROS which damage DNA and set the stage for genomic instability upon reoxygenation [29]. Hypoxia promotes polyploidy, the duplication of the genome without cell division and is associated with genomic instability and defective apoptotic pathways and mitotic checkpoints [30]. 
Overall, hypoxia results in the differential regulation of genes and enzymes involved in the DNA repair and replication stress response, generally resulting in cancer cells with unchecked cell cycle arrest and decreased apoptosis signaling [21].

The inhibition of the two primary DNA double-strand break (DSB) repair pathwayshomologous recombination (HR) and non-homologous end joining (NHEJ)—is associated with genetic instability and cancer. DSBs involve the breaking of DNA phosphor-sugar backbones and the dissociation of DNA into two separate molecules and can originate from endogenous ROS production, ionizing radiation, or the activity of DNA alkylating agents [31]. In NHEJ, a Ku70/80 heterodimer binds to the site of the DSB and recruits the DNA-dependent protein kinase catalytic subunit which initiates the repair signaling cascade [32]. In contract, homology-directed repair requires sequence homology to align DSB ends and is mediated by recombinase factors such as RAD51, RAD52, BRCA1, and BRCA2. Under hypoxia, the functional activity of DNA repair enzymes and the expression of mismatch repair genes $M L H 1$ and $M L H 2$ and homologous recombination mediators $B R C A 1$ and RAD51 is repressed [33-36], leading to the amplification of damaged DNA and survival suited to a low oxygen microenvironment. ROS production can also result in single-strand breaks, which are repaired with the help of poly(adenosine diphosphate)ribose polymerase 1 (PARP-1) protein, and inhibition of SSB repair causes an increase in DNA lesions and DSBs. PARP proteins 1-3 have been key cancer targets; in fact, three PARP inhibitors (Olaparib, Rucaparib, and Niraparib) have been approved by the Food \& Drug Administration to treat ovarian cancer [37]. For additional discussion on mechanisms of hypoxia and other DNA repair processes such as non-homologous end joining, mismatch repair, and nucleotide excision repair, please refer to the following review [38].

\subsection{Metastasis}

Hypoxia is known to modify gene expression profiles in a fashion that promotes cellular adaptation, survival, and metastasis (Figure 1). Certain physiological environments such as the bone marrow are more hypoxic than others, and surviving metastasis would require adaptation to the unique cellular and molecular niches of distant sites. A metastatic tumor cell must remodel its extracellular matrix (ECM) to detach from the primary tumor site, migrate, and extravasate, before arriving at and proliferating in the metastatic site. Studies show a link between hypoxia and migration, invasion, and metastasis in gastric cancer cells, fibrosarcoma, cervix carcinoma, and melanoma [39-42]. Oxygen tension values $<10 \mathrm{mmHg}$ are associated with an increased mortality rate and risk of metastasis in cancers of the breast, cervix, brain, head, and neck [43]. Hypoxia upregulates genes related to metastasis such as osteopontin $(O P N)$, plasminogen activator urokinase receptor (PLAU), and lysyl oxidase $(L O X)$, which increases invasion and cell adhesion to the extracellular matrix $[44,45]$. Breast cancer and Waldenström macroglobulinemia cells exposed to acute hypoxia for $24 \mathrm{~h}$ in vitro and injected into mice by the tail vein have demonstrated a greater metastatic capacity than equivalent normoxic cells [46,47]. In addition, using an in vivo reporting system to irreversibly identify hypoxic cells, Godet et al. found that breast cancer tumor cells exposed to hypoxia develop an ROS-resistant phenotype and are more prone to survival, invasion, and metastasis [19]. Intermittent but not chronic hypoxia promoted metastasis, clonal diversity, and stem cell marker expression in breast cancer cells [48]. This evidence indicates that hypoxia is closely linked to the metastatic phenotype in cancer.

\subsection{The CSC Phenotype}

While hematopoietic stem cells have been studied for 60 years or so, cancer stem cells (CSCs) are a relatively recent discovery from the late 1990s. CSCs are defined as a subpopulation of cancer cells resembling embryonic stem cells and possessing sphere-forming potential, an undifferentiated profile, and the capacity to self-renew and proliferate longterm. Dormant and therefore therapy-resistant, CSCs or tumor-initiating cells are often responsible for relapse and can be characterized by the expression of numerous biomarkers such as CD44, CD24, CD29, CD49f, ALDH, CD105, CD133, or CD166, depending on the 
cancer type [49-52]. For instance, the most commonly used expression profile for breast cancer stem cells is $\mathrm{CD}_{4} 4^{+} / \mathrm{CD}_{2} 4^{-/ \text {low }}$ and $\mathrm{ALDH}^{+}$[52]. Through flow cytometry and FACS (Fluorescence-activated Cell Sorting) sorting, CSCs have been identified in hypoxic tumor microenvironments (TMEs) of esophageal, renal, gastric, ovarian, and breast cancer [49-51,53]. Studies have shown that as low as $100 \mathrm{CD} 44^{+} / \mathrm{CD} 24^{-/ \text {low }}$ cancer cells of the brain, breast, pancreas, lung, and colon can initiate tumors, while greater than 10,000 cells of other non-CSC counterparts were unable to [54-57]. One study presents evidence that there is turnover and new formation of CSCs in an MMTV-PyMT mouse model of breast cancer [58], that is in line with the plasticity of CSC populations. It is reasonable to speculate that hypoxia and appropriate environmental conditions may promote a bias toward the CSC phenotype. Hypoxia is associated with the loss of differentiated gene expression in hypoxic neuroblastoma and breast cancer cells $[59,60]$ which can promote immortalization and tumor aggressiveness. In addition, hypoxia induces cell cycle arrest, the expression of dormancy genes, and epigenetic modifications such as repressive H3K27me3 found in dormant cells [61]. HIF signaling also upregulates markers of the stem cell phenotype-SOX9, SOX2, c-MYC, OCT4 and NANOG-in 11 cancer cell lines [62].

Stem cell-like properties and the epithelial-to-mesenchymal transition (EMT) are intimately connected as embryonic stem cells have been observed to show EMT characteristics, and cells undergoing EMT can acquire a stem cell-like phenotype [63,64]. Although physiologically necessary for embryogenesis, gastrulation, and tissue regeneration, EMT is also considered an early step in cancer metastasis and is associated with pathological organ fibrosis, cancer migration, and chemo- and radio-resistance [65]. In fact, EMT is an important prognostic factor in oral squamous cell carcinoma (OSCC), the most common form of oral cancer [66]. EMT is dependent on transforming growth factor (TGF)- $\beta$ and the expression of mesenchymal-associated N-cadherin, Vimentin, Snail, and Slug, while inversely related to p53-mediated apoptosis and levels of epithelial-associated E-cadherin (E-cad) [67]. The loss of E-cad is a cornerstone of EMT and is directly regulated by Snail, ZEB, and KLF8, while Twist and Goosecoid are known to indirectly inhibit E-cad [68]. EMT in non-small cell lung cancer (NSCLC) is associated with cell elongation, increased cell motility, and loss of cell-cell adhesion, mediated by HIF1-inducible Snail1 and TWIST [69]. In addition, hypoxia and the subsequent stabilization of HIF- $1 \alpha$ promotes EMT in pancreatic cancer cells through NF- $\kappa$ B and TGF- $\beta$ signaling $[70,71]$. NF-kB upregulates anti-apoptotic gene expression and is likely a factor for chemoresistance in tumors with mutated tumor suppressor KRAS [72,73]. EMT markers are associated with greater resistance to small molecule EGFR kinase inhibitors in cancer cells of the colon, bladder, pancreas, lung, head, and neck with, and restoring E-cad abrogates this resistance [74-77]. Snail is associated with resistance to paclitaxel, adriamycin, radiation, and dendritic cell immunotherapy in ovarian cancer cells via inhibition of p53-dependent apoptosis [78,79]. In other words, hypoxia induces HIF signaling which upregulates stem cell and EMT markers, promoting associated chemoresistance.

The interactions between cancer stemness and the immune system, described in more detail in another review [80], are another burgeoning field. The CSC phenotype is negatively correlated with natural killer $(\mathrm{NK})$ cells, B cells, and activated CD4 ${ }^{+}$and CD8 ${ }^{+}$ $\mathrm{T}$ cells in pancreatic cancer and other solid tumors [81,82].

\subsection{Resistance to Radio- and Chemo-Therapy}

Accompanying the complexities of cancer are the multitude of interventions and therapeutics to eradicate it. Nowadays, patients and physicians can consider chemo- and radiotherapy, immunotherapy, and even gene therapy, and treatment management is increasingly more targeted and personalized. However, despite gains and successes in cancer treatment, a cancer cure is far from the horizon, and much work is still needed to further our understanding of the mechanisms of cancer resistance so that treatment can be tailored to maximize cancer eradication in the patient. A minority of patients respond to immunotherapy, and solid tumor heterogeneity complicates the efficacy of chimeric antigen 
receptor (CAR)-T cell immunotherapy. The most commonly used anticancer treatment is still chemotherapy, but subpopulations of cancer cells, often CSCs, can survive from treatment, proliferate, and become obstacles to disease-free remission [83].

Therapeutic successes are often hindered by the hypoxic niche which not only affects tumor itself by reversibly inducing cellular senescence and selecting for a proliferative and metastatic cell phenotype, but also interferes with drug delivery and the cellular uptake of chemotherapeutics. Chemosensitivity depends on the distribution of blood flow within tumors; thus, the irregularity of vascular networks surrounding tumors is correlated with the inconsistent delivery of chemotherapeutic agents. In addition, the altered $\mathrm{pH}$ gradients as a result of hypoxia can disrupt the activity of $\mathrm{pH}$-dependent chemotherapeutics (doxorubicin and docetaxel) and DNA alkylating agents, such as temozolomide, chlorambucil, and ifosfamide $[84,85]$. Hypoxia is already implicated in chemoresistance to doxorubicin, bleomycin, and platinum-based drugs $[76,86]$. One complication of antiangiogenic drugs, sutinib and bevacizumab, is exacerbation of the hypoxic niche and the subsequent expansion of the CSC population in breast cancer [87]. At the cellular level, hypoxia activates multidrug resistance 1 (MDR1), encoding drug efflux pump P-gp, which works to remove intracellular chemotherapeutic drugs, in a HIF-1-dependent manner [88]. The drug action of etoposide which inhibits DNA synthesis is hindered by hypoxia, and liver and breast cancer cells exposed to hypoxia developed more resistance to etoposide than normoxic cells via TMEM45A expression [89]. Overall, hypoxia in solid tumors alters tissue morphology and cellular characteristics in ways that limit the efficacy of many chemotherapeutic agents.

The efficacy of irradiation treatment owes itself to the mechanism of "oxygen fixation" in which free radicals, the products of ionizing radiation, react with oxygen molecules within cells and irreversibly damage DNA. However, in hypoxic cellular environments, this process occurs less profoundly, and cells can survive. Initial observations in the 1930s found that low oxygen tension and the dearth of oxygen radicals hinders the cytotoxic effects of $X$ - and $\gamma$-irradiation [90], and up to three times the radiation dose is needed in hypoxic cells to have similar cytotoxic effects as normoxic cells [91]. Radiosensitivity also depends on cell state (i.e., cell cycle phase), the type of radiation, and oxygen levels in the target tissue region [5]. In vitro and in vivo studies have shown that both short-term and long-term hypoxia result in increased resistance in radiotherapy [92-94]. The hypoxiainduced increase in VEGF contributes to angiogenesis which promotes disease recurrence after irradiation [95].

In general, hypoxia causes extensive genomic changes and shifts in transcriptional responses which in turn affect metabolic programming and phenotypic expression (Figure 2). Hypoxia is associated with an upregulation in metabolic genes enriched for drug metabolism and pyrimidine and purine synthesis [96]. HIF-1 also activates glycolysis-related genes such as GLUT1, GLUT3, PDK1, GAPDH, ENO1, and LDHA [97]. Hypoxia can also augment the uptake of fatty acids and glutamine, the latter of which can be converted to oncometabolites (e.g., 2-hydroxyglutarate (2-HG), fumarate, and succinate) and be used for ATP synthesis that promotes tumor proliferation [98]. 2-HG can also affect the activity of oxygen-dependent enzymes such as JmjC histone demethylases and DNA demethylases [99]. Shifts to anaerobic glycolysis and lactate production in tumor cells not only lowers extracellular $\mathrm{pH}$ which affects drug effectiveness and the immune response [100], but also increases adenosine levels which is known to suppress T cells [101]. In addition, hypoxia decreases the expression of genes related to the pentose phosphate pathway (e.g., G6PD, PGLS, PGD, TKT, and TALDO1) while upregulating those associated with glycolysis (HK2, PFKP , LDHA) in glioblastoma [102,103]. However, not all cancer cells shift to glycolysis under hypoxia; a bias toward mitochondrial oxidative phosphorylation is observed in certain leukemias, lymphomas, pancreatic ductal adenocarcinoma, endometrial carcinoma, and chemo-resistant melanoma [104]. Breast cancer cells highly metastatic to the brain had high levels of cholesterol, membrane lipids, and metabolites associated with the pentose phosphate pathway and low levels of triacylglycerols, which reflects the brain physiological environment [105]. A connection between hypoxia and the metabolic adaptations in 
line with the seed-and-soil hypothesis is yet to be investigated. Cancer cell metabolism is dynamic and influences tumor growth, survival, and metastasis in ways unique to different cancers and in vivo contexts; nevertheless, investigating the metabolic effects of hypoxia can potentially reveal novel therapeutic targets and ways to overcome cancer resistance.

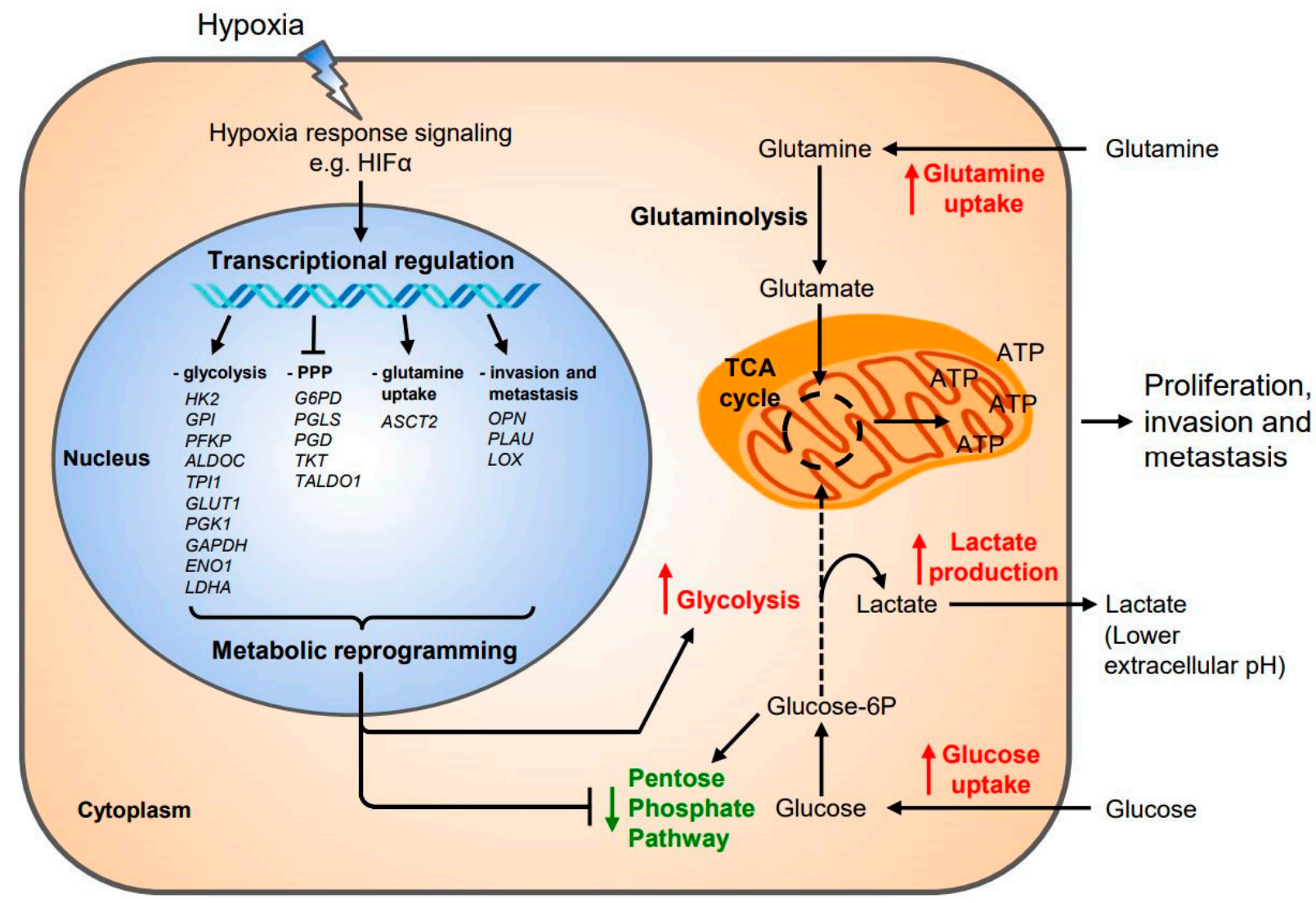

Figure 2. The Transcriptional-Metabolic Interactions under Hypoxia. A variety of genes upregulated transcriptionally under hypoxia affect cancer cell metabolism and behavior. The balance of glycolysis and oxidative phosphorylation along with the amounts of cholesterol, triacylglycerols, and other metabolites can metabolically "prime" a cancer cell to seed at specific organs during metastasis. HK2: Hexokinase 2; GPI: Glucose-6-phosphate isomerase; PFKP: 6-phosphofructokinase platelet type; ALDOC: Aldolase C; GLUT1: Glucose transporter protein type 1; PGK1: Phosphoglycerate kinase 1; GAPDH: Glyceraldehyde-3-phosphate dehydrogenase; ENO1: Enolase 1; LDHA: Lactate dehydrogenase-A; G6PD: Glucose-6-phosphate dehydrogenase; PGLS: 6-phosphogluconolactonase; PGD: 6-phosphogluconate dehydrogenase; TKT: Transketolase; TALDO1: Transaldolase 1; ASCT2: Alanine-serine-cysteine transporter, type-2; OPN: Osteopontin, PLAU: Plasminogen activator urokinase receptor, LOX: Lysyl oxidase; UPR: Unfolded protein response; TCA: Tricarboxylic acid; ATP: Adenosine triphosphate.

A more nascent field explores the role of hypoxia in immunosuppression, immune evasion, and resistance to immunotherapy, which is summarized in another review [106]. Overall, hypoxia elicits complex cellular adaptations comprising genetic and phenotypic modifications which ultimately lead to a malignant phenotype of metastasis and resistance to anti-cancer therapies. A few known mechanisms of these cellular changes will be discussed in the following section.

\section{Key Drivers of Hypoxia-Mediated Resistance and Metastasis \\ 3.1. Hypoxia-Inducible Factors}

HIFs are the predominant mediators of a cell's metabolic and physiological response to hypoxia and have increasingly been found to influence EMT, metastasis, and chemoresistance. HIF signaling can be activated by the PI3K, AKT, MAPK, and NF-kB pathways which can be activated by cytokines such as TNF- $\alpha$, chemokines, G protein-coupled re- 
ceptors, Toll-like receptors, and other factors [5]. In triple-negative breast cancer (TNBC), HIF-1 accumulation occurs as a result of glutamate secretion which inhibits the $x \mathrm{CT}$ glutamate-cystine antiporter leading to intracellular cysteine depletion [107]. The absence of cysteine under hypoxia subsequently inactivates prolyl hydroxylase EglN1 which usually facilitates HIF-1 $\alpha$ degradation in normoxia [107]. Other pathways such as PI3K/AKT signaling, in conjunction with a HIF-1-induced transcriptional response, induced cisplatin chemoresistance and EMT marker expression in hepatocellular carcinoma (HCC) cells [108]. Numerous associations have been highlighted between HIF levels and metastasis, disease recurrence, and poor prognosis in ovarian, breast, thyroid, and lung cancers [109-112]. HIF- $1 \alpha$ expression is associated with reduced disease-free survival and a poorer response to hormone-based therapy in breast cancer [113].

In hypoxic conditions, HIFs are stabilized because of the inhibition of oxygen-dependent dioxygenases which modify HIFs under normoxia, enabling its degradation. The stabilization of HIF allows for binding at consensus sequences on DNA and the recruitment of p300, RNA polymerase II, and cofactors so that target genes are transcribed. The downstream effects of increased HIF signaling include regulation of the expression of genes involved in glucose metabolism, erythropoiesis (EPO), vascularization (VEGF, SDF1, KITL), tissue remodeling (LOX), and wound healing (TGFA) [114]. Chromatin immunoprecipitation assays reveal over 1,000 genes regulated by HIF-1 [115], but only a subset of the extensive transactivation, usually 100 genes, is typically observed in a given cell [116].

While there is substantial sequence and structural homology between HIF-1 and HIF-2, they carry out different functions. HIF- $1 \alpha$ is the major factor that contributes to target gene transactivation, tumorigenesis, and metastasis in the TNBC cell line, MDA-MB-435 [117]. Both HIF- $1 \alpha$ and HIF- $2 \alpha$ activate VEGF and form complexes with the c-Myc oncoprotein to regulate transcription [118]. However, HIF-1 $\alpha$ inhibits c-Myc activity, whereas HIF- $2 \alpha$ potentiates it [119]. In addition, HIF-1 $\alpha$ uniquely activates glycolytic enzymes phosphoglycerate kinase (PGK) and aldolase A (ALDA), glucose transporter GLUT1 (or SLC2A), stem cell marker OCT4, the $\mathrm{pH}$ regulator, carbonic anyhydrase IX (CA9), and EMT-associated transcription factors Zeb, Snail, and TWIST [120-122]. Specifically, CA9 is a prognostic factor, hypoxic indicator, and promising therapeutic target, as inhibiting CA9 can enhance anti-PD-1 and anti-CTLA-4 blockade in melanoma and breast cancer models [123]. In addition, additional targets of HIF- $1 \alpha$ include the Wnt and Notch pathways which contribute to EMT, and LOX which activates Snail, represses E-cad, and contributes to chemoresistance in TNBC [121,124-126]. Interestingly, HIF-1 $\alpha$ but not HIF-2 $\alpha$ appears to regulate extracellular acidification in hypoxic tumors while both isoforms contribute to radioresistance in NSCLC [127]. HIF-2 has been identified as the principal oncogenic HIF isoform in clear cell renal cell carcinoma (ccRCC), contributing to a "pseudo-hypoxic" cell state, and has been implicated in pathogenesis, EMT, and angiogenesis in NSCLC [128]. HIF-2 controls cell differentiation and adaptive responses to hypoxia [129,130], along with erythropoiesis [131,132]. The functions of HIF-3 $\alpha$ are more elusive due to multiple splicing variants that make functional characterization of the isoform challenging in research. HIF-1 $\alpha$ expression can be induced by nitric oxide and ROS [133], but there are also hypoxiaindependent mechanisms of regulating HIF by the PI3K/AKT/mTOR pathway, cytokines, epigenetic changes, and lipopolysaccharides, which are not discussed in this review [134].

Recent research has revealed the intersectionality between HIF-1, angiogenic signals, and metastasis. HIF-1 is known to promote vascularization of tumors through the upregulation of VEGF, which in one mechanism, binds to VEGFR2 receptors on bone marrow cells (BMCs), mobilizing the cells to promote angiogenesis [135]. The anthracycline doxorubicin prevents angiogenesis and tumor growth by reducing HIF-1 signaling and the circulation of these BMCs [135]. Similarly in melanoma and lung cancer, colonizing tumor cells produce VEGF-A, LOX, TNF- $\alpha$, and inflammatory serum amyloid A3 in a HIF-1-dependent manner which leads to the recruitment of bone marrow-derived cells, metastatic niche formation, and remodeling of the extracellular matrix to facilitate invasion [136]. HIF-1 $\alpha$ also regulates extracellular matrix metalloproteinase inducer which is induced by hypoxia 
and promotes metastasis and EMT in esophageal cancer cells [137]. HIF-1 also induces the expression of L1 cell adhesion molecule which allows breast cancer cells to adhere to blood vessel endothelial cells and metastasize to the lung [138]. A study using a mouse model of melanoma found that inactivation of HIF- $1 \alpha$ or HIF- $2 \alpha$ had no change in tumorigenesis but significantly reduced metastasis, suggesting a specific function of HIF in metastasis [139]. Interestingly, in MDA-MB-231, a human TNBC cell line, VEGF-D is inversely correlated with hypoxia and metastasis to lymph nodes, while platelet-derived growth factor B (PDGF-B) was found to be directly activated by HIF-1 and to facilitate lymphatic metastasis [140].

Glycolysis-related HIF-1-transactivated genes might also be a driver in metabolic reprogramming that occurs during metastasis; for instance, HIF-1 activates monocarboxylate transporter 4 (MCT4) expression which promotes the transport of lactate into the ECM, acidifying the TME and favoring pre-metastatic remodeling of ECM [141]. In addition, the metastatic site likely selects for particular metabolic and enzymatic profiles that enable tumor cells to survive. Pyruvate dehydrogenase kinase (PDK1) and glycolytic metabolism facilitated breast metastases to the liver more so than to the bone or lung [142].

In addition to the altered milieu of intracellular and extracellular metabolites, hypoxic tumors develop mechanisms that resist the antitumor immune response. The HIF-1mediated production of TGF- $\beta$, VEGF, and CCL28 contributes to immunosuppression in the TME via the recruitment of regulatory $\mathrm{T}$ cells $\left(\mathrm{T}_{\text {regs }}\right)$, macrophages, and myeloidderived suppressor cells [143]. $\mathrm{T}_{\text {regs }}$ are partially responsible for tumor immune tolerance, angiogenesis, and metastasis. Additionally, adenosine production and secretion, associated with an immunosuppressive environment, is increased under hypoxia as a result of the HIF$1 \alpha$ mediated upregulation of CD73 and CD39 [144]. HIF-1 upregulates PD-L1 expression in tumors leading to the overstimulation and exhaustion of $\mathrm{T}$ cells, blocking their cytotoxic functions [145].

Hypoxia enriches a chemo-resistant CSC population in TNBCs treated with cytotoxic paclitaxel or gemcitabine both in vitro and in vivo through HIF-1 $\alpha$ expression [146]. The increase in proportion of breast CSCs was coincided with increased IL-6, IL-8, MDR1, and ROS, and this expression was inhibited with the coadministration of HIF inhibitors digoxin or acriflavine [146]. Both HIF-1 $\alpha$ and HIF-2 $\alpha$ are known to activate Notch signaling and "stemness" and EMT transcription factors [62,147] which can consequently interact with the Wnt pathway and regulate the stem cell phenotype. Leukemic cells that have adapted to hypoxia exhibit stem cell-like properties along with increased HIF- $1 \alpha, \beta$-catenin, and glyoxalase-1 activity, an enzyme that detoxifies the harmful glycolytic by-product, methylglyoxal [148]. In this way, hypoxia-induced metabolic, transcriptional, and molecular alterations converge enabling subpopulations of treatment-resistant, stem cell-like cancer cells to survive and contribute to disease relapse.

HIFs drive processes that affect metabolism and cellular behavior, but conversely, EMT and environmental factors such as drug administration can affect cancer metabolism and transcriptional responses. Despite the pervasive influence of HIF pathways on the hypoxic response, some HIF-independent mechanisms for metastasis, EMT, and resistance to therapy may exist in different cancer types and stages.

\subsection{Oxoglutarate-Dependent Dioxygenases}

2OGDDs are a diverse superfamily of enzymes (e.g., prolyl hydroxylases, JmjC (Jumonji C) domain histone lysine demethylases (KDMs), ten-eleven translocation (TET) DNA hydroxylases, and RNA demethylases such as FTO and ALKBH1-3, 5) that facilitate numerous biological processes, including the HIF-mediated response to hypoxia, ECM formation, DNA and histone modifications, and normal and cancer cell metabolism. 2OGDDs hydroxylate their substrate with the assistance of oxygen, 2-oxoglutarate, and $\mathrm{Fe}^{2+}$ and produce succinate in the reaction [15]. In the canonical response to hypoxia, a specific class of 2-OGDDs, prolyl hydroxylase domain proteins, hydroxylate prolyl residues of HIF (Pro402 and Pro564 in HIF-1 $\alpha$; Pro405 and Pro531 in HIF-2 $\alpha$; Pro492 in HIF-3 $\alpha$ ) which 
enable the von Hippel-Lindau protein to ubiquitinate HIF- $\alpha$ and tag it for degradation by proteasomes [13]. While dysregulated 2OGDDs have been implicated in many cancers, cancer-related metabolic alterations can also influence 2OGDDs. PHDs (or EgINs) are inhibited by oncometabolites succinate and fumarate, which accumulate under hypoxia, and 2OGDDs can also be targets of HIF signaling.

Various 2OGDDs have been linked to the development of the CSC phenotype and chemoresistance. PHD2 (EglN1) is inhibited by TGF- $\beta$ a major factor for EMT and metastasis, resulting in the stabilization of HIF-1 and the enhancement of EMT pathways [149]. In addition, PHD1 (EgIN2) inhibition and silencing sensitizes colorectal cancer cells to 5-FU chemotherapy [150]. KDM5A and KDM5B are associated with transcriptomic heterogeneity and therapy resistance in luminal breast cancer and melanoma [151,152]. Loss of KDM6A, a known tumor suppressor, contributes to histone hypermethylation, a phenomenon common in hypoxic tissues, and was found to prevent cellular differentiation under hypoxia, independently from HIF [153]. Likewise, KDM6A and KDM5C are often mutated in ccRCC ( $3 \%$ and $8 \%$ of tumors, respectively) [154,155]. KDM6A is also mutated in numerous solid tumors such as bladder cancer, prostate cancer, and breast cancer [156], and depletion of KDM6A led to increased expression of EMT transcription factors, Snail, ZEB1, and ZEB2 [157]. ALKBH5, an m6A RNA demethylase, is responsible for a HIF-1mediated increase in NANOG expression and the induction of a CSC phenotype in breast cancer [158]. Overall, targeting oncogenic 2OGDDs has potential to not only inhibit tumor growth and CSC features but also enhance existing anticancer therapies.

\subsection{The Unfolded Protein Response Pathway}

Oxygen is a necessary electron acceptor to facilitate disulfide bond formation in protein folding, but under severe hypoxia, impaired protein folding, along with HIF-1-related metabolic switches, mitochondrial stress, or ROS activity can activate the unfolded protein response (UPR) pathway [159]. Although the UPR signaling cascade typically promotes cell survival and adaptation to hypoxia by regulating protein production, degradation, and cell metabolism, it can also induce cell death [160]. The UPR can be characterized by three major endoplasmic reticulum (ER) stress sensors: the PRKR-like endoplasmic reticulum kinase (PERK), inositol-requiring enzyme 1 (IRE1), and the ATF6 pathway (Figure 3) [161]. Together, to mediate ER stress, UPR signals transiently suppress mRNA translation and protein biosynthesis and activate protein degradation and cellular apoptosis [161].

Mechanistically, PERK interacts with and phosphorylates eukaryotic initiation factor 2a (eIF2a) which regulates translation of downstream effectors such as activating transcription factor 4 (ATF4). The PERK-ATF4 branch is known to trigger CREB3L1 activity which contributes to metastasis and EMT in breast cancer [162]. The PERK-eIF2a arm of the UPR has been linked to hypoxic cancer cell survival and tolerance to radiotherapy in a colorectal cancer cell line through a mechanism of glutathione synthesis and mitigation of the effects of ROS [163]. Separately, Yoneda et al. demonstrate that IRE1, another UPR transducer, facilitates the interaction of HSP47, a chemical chaperone, with non-muscle myosin IIA, contributing to aggressive metastasis in breast cancer [164]. The expression of XBP-1, another substrate of IRE1, was found to drive TNBC growth and invasiveness, and correlated with hypoxia-mediated HIF- $1 \alpha$ gene signatures [165]. Interestingly, the IRE1-XBP-1 axis is also responsible for the downregulation of c-Myc and activation of NK cells which protected against melanoma [166]. In addition, the fact that UPR inhibitors such as 4-PBA and TUD-CA can stall tumor growth and metastasis [167] suggest that the UPR pathway may present as a potential anticancer target. Interestingly, researchers have found that KDM1A inhibitors are able to induce differentiation in glioma stem cells by activating the UPR [168], and ATF4 stability is mediated by PHD3 [169], speaking to the complex and understudied overlap of 2OGDDs with the UPR. 


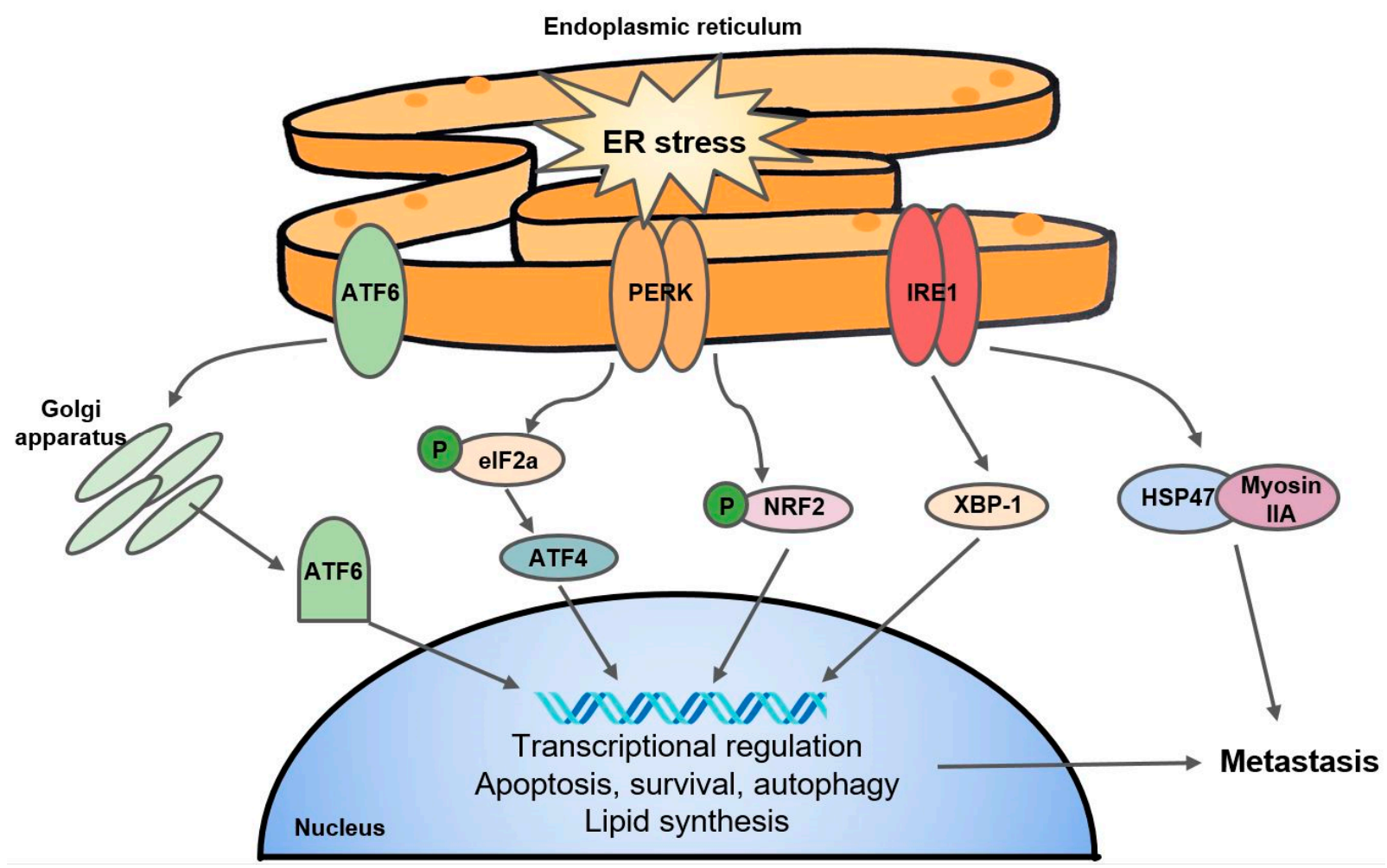

Figure 3. A simple schematic of the UPR. The three major arms of the UPR consist of ATF6, PERK, and IRE1. ATF6: activating transcription factor; PERK: PRKR-like endoplasmic reticulum kinase; IRE1: inositol-requiring enzyme 1; eIF2a: eukaryotic initiation factor 2a; NRF2: Nuclear factor erythroid 2-related factor 2; XBP-1: X-box binding protein 1; HSP47: heat shock protein 47 .

\subsection{Other Emerging Pathways, from Exosomes to Noncoding RNAs}

Exosomes or microvesicles are nanosized vesicles secreted extracellularly that aid in cell-cell communication and sculpting the TME. Able to carry proteins, lipids, microRNAs, or mRNAs, exosomes have been associated with cancer progression, angiogenesis, and EMT. Hypoxia induces the increased release of exosomes in glioblastoma cells along with ovarian, breast, and prostate cancer cells [170-173]. Hypoxia also influences the composition of molecules within exosomes, such as increasing amounts of triglycerides, metalloproteinases, IL-8, LOX, and heat shock proteins, and inducing the exosomal secretion of miRNAs that induce angiogenesis and stemness [170,174-176]. Ovarian cancer cells upregulate the exosomal efflux of cisplatin when treated with the drug, and inhibiting exosome release using Amiloride impaired tumor cell proliferation [173]. Exosomes derived from CSCs promote the survival of immunosuppressive neutrophils, ultimately accelerating colon cancer growth [177]. The secretion of exosomes may in part be mediated by HIF-1 $[178,179]$. Overall, these data suggest that hypoxia-induced exosomes may contribute to tumorigenesis and chemoresistance.

Mitochondrial dynamics such as mitochondrial fission and motility influence cell survival, morphology, and ROS homeostasis which may affect EMT and metastasis. For instance, the distribution and motility of mitochondria which is dependent on MIRO1 and MIRO2, Rho-GTPases that regulate mitochondrial movement through anchorage to kinesin or dynein, has been found to influence cancer metastasis [180]. In addition, Dynamin related protein 1 (Drp1) facilitates mitochondrial fission and is upregulated by hypoxia in MDA-MB-231 TNBC cells; silencing of Drp1 reduced mitochondrial fission, ROS production, apoptosis, and migration in TNBC cells [181]. While there is evidence linking Drp1 with stemness in ER-positive breast cancer cells [182], there is a need for additional research to definitely link mitochondrial fission and other dynamics with the CSC phenotype. Previously, our research indicated that PHD1 (EglN2) promotes the 
binding of peroxisome proliferator-activated receptor- $\gamma$ coactivator (PGC1 $\alpha$ ) with NRF1 under hypoxia and subsequently maintains microchondrial biogenesis in breast cancer through inducing transcription of ferridoxin reductase (FDXR) [183]. Recently, proteintyrosine phosphatase mitochondrial 1 (PTPMT1), an enzyme essential for cardiolipin biosynthesis and mitochondrial membrane integrity, was identified in a genome-wide CRISPR-Cas9 knockout library screening as a crucial survival factor for HCC cells under hypoxia [184].

PTPMT1 regulates cardiolipin synthesis and facilitates the assembly of the ETC complexes which alleviates ROS accumulation during hypoxia. Depletion or pharmacological inhibition of PTPMT1 decreases tumor growth, disrupts the mitochondrial membrane and ETC formation, and reduced metastasis in different cancers [184]. In addition, hypoxiainduced mitochondrial stress is a hallmark of intra-tumoral $\mathrm{T}$ cells with persistent antigen stimulation. These exhausted T cells have repressed PGC1 $\alpha$ and are less able to mitigate the effects of ROS, suggesting that hypoxia-induced ROS might be connected to T cell exhaustion and dysfunction [185]. By targeting and reversing hypoxia, terminal T cell exhaustion can be prevented, increasing the efficacy of checkpoint blockade immunotherapy [185].

The effects of microRNAs (miRNAs) on metastasis, the CSC phenotype, and resistance to antitumor therapies are an understudied field. MiRNAs, while too short to encode proteins themselves, can inhibit the translation of mRNA or facilitate the degradation of target mRNA. With the potential to regulate the expression of a variety of proteins, miRNAs can be tumor suppressive or oncogenic. Hypoxia-mediated miRNA, miR-210, was upregulated in the CSC subpopulation of MCF-7 breast cancer cells, and suppressed E-cadherin and upregulated Snail expression in the breast CSC population [186]. On the other hand, hypoxia-inducible miR-155 repressed homology-directed repair factors such as RAD51 in breast cancer cells and enhanced sensitivity to irradiation [187]. A review paper provides a list of miRNAs that contribute to resistance to chemotherapy agents in many cancers including those of the breast, ovary, stomach, colon, and lung [188].

Several studies have pointed out the role of long noncoding RNAs (lncRNAs), noncoding strands of RNA longer than 200 nucleotides, in regulating cancer development. A substantial proportion of single-nucleotide polymorphisms linked to risk in cancers are encoded on lncRNAs, and like miRNAs, lncRNAS can also regulate mRNA translation and degradation [189]. LncRNAs have been found to promote metastasis in OSCC by operating through pathways known to induce EMT such as the AKT, Wnt, and NF-kB pathways [190-192]. Recently, it was discovered that RAB11B-AS1, a lncRNA transcriptionally induced by HIF-2, promotes angiogenesis and metastasis in TNBC tumors grown in mice through the upregulation of VEGFA and ANGPTL4 [193].

The relationship between circular RNA, defined as single-stranded noncoding RNA that forms a continuous loop via a covalent bond between $3^{\prime}$ and $5^{\prime}$ ends, and cancer is a less studied field. One study reports that circHIPK3, mediated by HIF-2 $\alpha$, contributes to metastasis and invasion in hypoxia-adapted gastric cancer cells through the interaction with miR-653-5p and miR-338-3p and subsequent activation of the AKT pathway [194].

Histone deacetylases (HDACs) are a group of enzymes which modify chromatin structures by removing acetyl groups from lysine residues in histones and transcription factors and can therefore directly contribute to epigenetic and transcriptional alterations during cancer adaptation and survival under hypoxia. HDACs are frequently overexpressed across many cancer types and have been implicated in angiogenesis and cancer proliferation. HDAC1-3 repress miRNA-449 in HCC cells, allowing tumorigenic c-MET to promote growth signals [195]. HDAC6 enables $\alpha$-tubulin deacetylation in hypoxic conditions, allowing EMT factor, SMAD3, to translocate to the nucleus; HDAC6 inhibitors have been shown to inhibit metastasis in TNBC and angiogenesis in gastric cancer cells by reducing HIF-1 $\alpha$ and VEGF levels [196,197]. A recent study reveals a novel role for HDAC6 in glycolysis, and inhibition of HDAC6 not only decreases growth and invasion in TNBC but directly increases acetylation of glycolytic enzymes such as GAPDH, aldolase, and enolase [198]. 
Another outcome of hypoxia is autophagy, in which cellular stress induces the lysosomal degradation and recycling of proteins and damaged organelles into nutrients to maintain cell functions and promote survival. Together, HIF-1 signaling, hypoxia-mediated metabolic reprogramming, the UPR, and mTOR signaling converge on autophagy and ultimately contribute to tumor proliferation and metastasis [199]. Autophagy can be dependent on or independent of HIF-1 signaling, but it has been shown that HIF-1-mediated upregulation of autophagy genes beclin1 (BECN1) and ATG5 enabled lung tumor immune evasion [200]. In addition, BECN1 was responsible for an impaired natural killer cell-mediated antitumor immune response in breast cancer [201].

From miRNAs, lncRNAs, exosomes, and the UPR to the complex transcriptional responses induced by HIFs, hypoxia ignites an avalanche of responses that reconfigure cell metabolism, local tumor immunity and vasculature, and sensitivity to additional stressors such as chemo- or radiotherapy. The co-regulation, convergence, and interdependence of multiple pathways within a hypoxic tumor have great implications in the development and enhancement of anticancer treatments.

\section{From Mechanisms to Therapeutics}

Cancer therapy resistance remains a pressing medical problem, and $90 \%$ of failures in chemotherapy occur as resistant tumors metastasize and invade beyond the primary tumor site [188]. Developing multidrug resistance through drug efflux or detoxification, upregulating DNA repair pathways, and epigenetic reprogramming are a few mechanisms by which cancer cells become resistant [188]. Targeting hypoxia-induced mechanisms of resistance can increase the efficacy of anti-cancer therapeutics. Therapeutics with optimal efficacy must exhibit and maintain targeted lethality to tumors while considering tumor transcriptional and genetic heterogeneity and extrinsic factors such as varied oxygen levels and $\mathrm{pH}$ within the TME. Various strategies to overcome resistance and reverse the hypoxic barrier include 1) tumor oxygenation via supplemental oxygen and oxygen transport agents (hemoglobin and fluorocarbons), 2) prodrugs whose antitumor effects are activated under hypoxia, and 3) pharmaceuticals that target hypoxia-induced pathways that lead to hypoxia tolerance and survival [85]. Since hypoxia-based treatments cannot completely cure cancer, these interventions are usually performed in combination with standard cancer therapies to enhance efficacy.

\subsection{Drugs That Target the Hypoxic Tumor Microenvironment}

Many chemotherapeutic drugs that are dependent on oxygen for their biological action fail to achieve success in eradicating advanced tumors. One strategy is to reverse tumor hypoxia through oxygen delivery. Tumor oxygenation using oxygen-carrying perfluorocarbon nanodroplets improved the efficacy of radiotherapy and photodynamic therapy in mouse models of breast and colon cancer [202]. Another method to address the hypoxic barrier is to design therapeutics with enhanced or activated cytotoxicity in the hypoxic TME. Originally derived from mitomycin-C which was found to be more cytotoxic in hypoxic conditions [203], hypoxia-activated prodrugs or bioreductive alkylating agents are one class of drugs with chemical signatures (e.g., nitroimidazole groups, azogroups, disulfide bonds, and transition-metal complexes) that can be responsive to reductive hypoxic environments. Such bioreductive prodrugs become "activated" by oxidoreductases and are converted to cytotoxic forms under hypoxia and selectively target poorly oxygenated cells [204]. Theoretically, chemotherapy or radiotherapy would kill less hypoxic regions of tumors, while prodrugs can complement by killing more hypoxic, resistant cancer cells. Mechanistically, prodrugs such as tirapazamine (TPZ) commonly interfere with DNA replication at the replication fork and inhibit cell proliferation [205]; however there are various drawbacks and considerations for using prodrugs. The first generation of prodrugs when used in combination with conventional chemotherapy were often too cytotoxic. In addition, their activation is dependent on the presence of reductases within hypoxic cancer cells which is an understudied field, and different rates of metabolic consumption 
of the prodrug, dependent on cell density, can affect whether the drug can penetrate all hypoxic region.

Numerous bioreductive prodrugs have demonstrated preclinical promise $[206,207]$ but fail to demonstrate efficacy in phase II clinical trials [207], possibly because of a physiological distinction between in vitro hypoxic conditions testing the drug and in vivo tumor environments in patients. Specifically, improving stratification of patients based on tumor hypoxia status (i.e., randomizing hypoxic biomarker-enriched or hypoxia-positive patients between treatment groups) would likely optimize the benefits of hypoxia-activated prodrugs and reduce the number of patients required for the clinical trial [208]. The failure of some Phase III trials (e.g., TPZ and TH-302/Evofosfamide) might be attributed to the lack of patient stratification which strongly indicates the need for determining a biomarker-positive threshold in Phase II trials [208]. More granular patient stratification can help distinguish hypoxic tumors that are more likely to be responsive to prodrugs. Overall, there is a need to develop methods to individually characterize the severity of hypoxia and genomic heterogeneity of tumors to better match patients with hypoxiatargeted therapeutics.

\subsection{Therapies Targeting Hypoxia-Mediated Pathways}

Given the complex interactions between hypoxia-induced signaling pathways, targeting a single factor is usually insufficient to halt cancer growth or eradicate tumors. HIF- $1 \alpha /$ HIF- $2 \alpha$ inhibitors can be categorized as indirect or direct. Indirect HIF inhibitors regulate upstream and downstream effectors in the HIF pathway, while direct inhibitors decrease HIF mRNA expression, protein synthesis, or DNA binding [209]. Numerous HIF inhibitors are undergoing clinical trials such as vorinostat for relapsed lymphomas, PT2385 and PT2977 for cCRCC, and CRLX101 plus bevacizumab for platinum-resistant ovarian, tubal, and primary peritoneal cancer [209]. PT2385 and PT2977 are closely related HIF-2 inhibitors that show promise in targeting a key tumor dependency in ccRCC $[210,211]$. HIF inhibition also prevents unwanted side effects of irradiation in glioblastoma such as vasculogenesis and disease recurrence [212]. Pharmacological agents that inhibit HIFs (YC-1, 2-methoxyestradiol, anthracyclines) decrease proliferation and metastasis in several types of cancer or can enhance the efficacy of conventional therapies. Treatment with YC-1, for instance, overcomes resistance to gefitinib in NSCLC cells by inducing the degradation of EGFR [213]. 2-methoxyestradiol targets the radioresistant, stem-like cell population in nasopharyngeal carcinoma and downregulates EMT and NF- $\mathrm{kB} / \mathrm{HIF}-1 \alpha$ signaling [214]. Idarubicin, an anthracycline, inhibits metastasis in neuroendocrine tumors by preventing the binding of HIFs to HREs [215].

The indirect inhibition strategy involves targeting HIF regulators (including some 2OGDDs) or HIF-mediated transcriptional responses. We have recently published on the therapeutic potential of targeting USP37, a deubiquitinase which reverses the degradation process of HIF-2 $\alpha$ in ccRCC [216]. Depletion of USP37 impairs ccRCC growth in 2D and $3 \mathrm{D}$ growth assays and in vivo kidney tumorigenesis and lung metastasis [216]; therefore, inhibiting USP37 could be a viable therapeutic approach in VHL-deficient or HIF- $2 \alpha-$ dependent tumors. In addition, an inhibitor of NF- $\mathrm{kB}$ activity, BAY 11-7082, prevented EMT and reversed resistance to gemcitabine in pancreatic cancer cells [70]. LBH589 (panobinostat), a pan-HDAC inhibitor that indirectly promotes the degradation of HIF- $1 \alpha$, demonstrates antitumor effects in HCC, pancreatic cancer, NSCLC, and glioblastoma [217,218].

2-OG oxygenase inhibitors can not only affect HIF stability as described in Section 3.2 but also alter mitochondrial respiration, cell metabolism, and survival. Particularly, we highlight gamma-butyrobetaine hydroxylase 1 (BBOX1) a 2-OG oxygenase which is known to regulate cellular bioenergetics, calcium balance, and mitochondrial respiration [219]. BBOX1 depletion and pharmacological inhibition results in the degradation of calcium channel protein IP3R3 which subsequently decreases glycolytic pathways, mTORC1 signaling, and TNBC cell growth [219]. Various 2-OG inhibitors and the disease contexts they have been tested in are highlighted below (Table 1). 
Table 1. Inhibitors of 2-OG Enzymes.

\begin{tabular}{cccc}
\hline Inhibitor & Target Protein(s) & Disease Context & References \\
\hline GSK1278863 & PHDs & Anemia of chronic kidney disease & {$[220]$} \\
FG-4592 & PHDs & Anemia of chronic kidney disease & {$[221]$} \\
Fisetin & TET1 & Renal cancer stem cells & {$[222]$} \\
Compound 10 and 13 & KDM5 & Lung cancer cell line A549 & {$[223]$} \\
NCDM-32B & KDM4 & Basal-like breast cancer & {$[224]$} \\
IOX1 & KDM3, KDM4 & Colorectal cancer and vascular smooth & {$[225,226]$} \\
GSK2879552 & KDM1A & muscle cells in atherosclerosis & {$[227]$} \\
FB23 and FB23-2 & Small cell lung carcinoma & {$[228]$} \\
Compound 71 & FLKBH3 & Acute myeloid leukemia & Prostate cancer cell line DU145 \\
Indenone derivative Compound 5c & ALKBH3 & Lung cancer cell line A549 & {$[229]$} \\
\hline
\end{tabular}

Current research has gravitated toward identifying synthetic lethality targets to overcome therapy-resistance and impair cancer growth. We recently identified TBK1 as a synthetic lethal target in VHL-deficient kidney cancer [231], and inhibitors of TBK1 such as BX795, CYT387 481 (momelotinib), and MRT67307 can boost the efficacy of immune checkpoint inhibitors [232]. In addition, the use of veliparib, a drug that targets PARP-1, in combination with RAD51 deficiency, resensitizes hypoxic tumor colon carcinoma cells to radiation [233].

Another emerging therapeutic direction is combinatorial treatments, especially those that target hypoxic signaling to enhance immunotherapy. The efficacy of $\mathrm{T}$ cell checkpoint blockade immunotherapy in typically unresponsive "cold" tumors such as prostate cancer is enhanced by the combination of a hypoxia-activated prodrug [234]. Recently, Zhou et al. report the use of nanoparticles loaded with sorafenib which reduce tumor hypoxia and trigger the immune response, and when combined with anti-PD-L1 immunotherapy, was able to prevent tumor growth and inhibit metastasis in hepatocellular carcinoma [235]. In addition, vascular normalization through VEGF blockade is an area of interest to assist with the recruitment of cytotoxic T cells to combat tumor resistance [106]. Finally, anti-adenosinergic drugs in combination with PD-1/PD-L1 therapy have reached clinical trials to treat renal cell carcinoma [236], and targeting the immunosuppressive HIF-1-adenosine axis might be a suitable approach to maximize the antitumor response during immunotherapy [237].

The need to fine-tune therapeutics for individual contexts can be demonstrated by the dual effects of hypoxia-induced oxidative stress (Figure 4); increased ROS is connected to metastasis, but unregulated oxidative stress also leads to cancer cell death [238]. Antioxidants $N$-acetyl-cysteine and vitamin $C$ are thought to be antitumor agents that inhibit HIF- $1 \alpha$ activity and genomic instability [133]. However, injecting $N$-acetyl-cysteine to subcutaneous melanoma tumors increased metastasis and survival of melanoma cells to the blood [239], suggesting that oxidative stress could inhibit metastasis in some in vivo contexts.

As VEGF is upregulated under hypoxia, numerous anti-angiogenic receptor tyrosine kinase (RTK) inhibitors have been developed to block angiogenesis and abrogate tumor growth. However, this is not curative and can exacerbate hypoxia and drive tumor resistance and metastasis. To address this issue, researchers have found that targeting the apelin pathway in combination with sunitinib, an RTK inhibitor, reduced primary tumor growth, local hypoxia, and metastasis in mouse models of breast and lung cancer [240]. In addition, the endogenous antiangiogenic agent semaphorin $3 \mathrm{~A}$, when overexpressed, can also enhance the efficacy of antiangiogenic drugs and reduce hypoxia and EMT in a mouse model of pancreatic neuroendocrine cancer [241].

The interconnectedness of metabolic pathways, immune cell interactions, and other aspects of hypoxia-driven cellular reprogramming is a current focus of cancer research and can aid in the identification of novel targets and vulnerabilities. As new mechanisms are elucidated, drug producers are able to consider targeting metabolic reprogramming, $\mathrm{pH}$ homeostasis, the DNA damage response, tumor immunity signatures, and other features 
of cancer cells. As research unravels the crosstalk of pathways that drive tumorigenesis, metastasis, and therapy resistance, it is of increasing importance to develop therapeutics that target multiple pathways in hypoxia-adapted cancer cells and to anticipate interactions and unintended physiological consequences of pharmaceuticals.

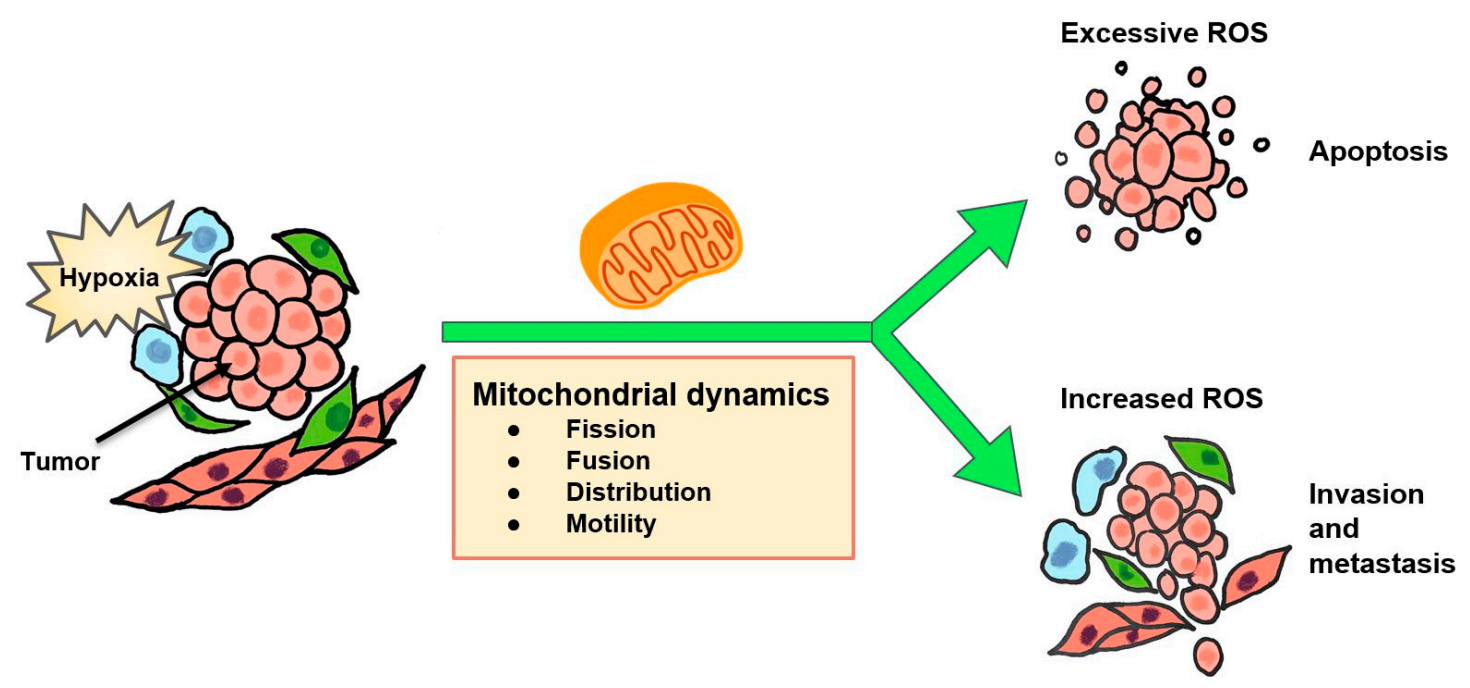

Figure 4. Mitochondrial dynamics may underlie redox homeostasis and the cellular response to hypoxia.

\section{Conclusions}

The numerous effects of hypoxia on cancer progression include changes in DNA repair mechanisms, cell metabolism, and tumoral immunity, along with transcriptional heterogeneity that contribute to the cancer stem cell phenotype, invasion, and resistance to chemo- and radiotherapies. Despite a lack of consensus on in vitro approaches to studying hypoxia, in vivo methods in more physiologically relevant contexts have provided insights to the crosstalk and interactions of numerous proteins and pathways that confer chemo- and radio-resistant, metastatic, malignant, or cancer stem cell-like phenotypes to tumors. Tumor hypoxia presents as a barrier to more effective chemo-, radio-, and immunotherapy. Nevertheless, inhibiting HIF has been a promising therapeutic avenue in disrupting tumor invasion, metastasis, and cancer stem cell enrichment. As cancer treatment increasingly involves combinatorial approaches, future clinical trial designs can include patient stratification based on hypoxic signatures. Understanding mechanisms of hypoxic adaptation can assist in devising more targeted therapies and enhancing the efficacy of current therapeutics.

Author Contributions: Writing—original draft preparation, R.S.; writing—review and editing, R.S., C.L., Q.Z.; supervision, Q.Z.; project administration, Q.Z.; funding acquisition, Q.Z. All authors have read and agreed to the published version of the manuscript.

Funding: Q.Z. is supported by Cancer Prevention and Research Institute of Texas (CPRIT, RR190058), ACS Research Scholar Award (RSG-18-059-01-TBE), National Cancer Institute (R01CA211732) and Department of Defense Kidney Cancer Research Program (KCRP) Idea Development Award (W81XWH1910813).

Institutional Review Board Statement: Not applicable.

Informed Consent Statement: Not applicable.

Data Availability Statement: Not applicable.

Acknowledgments: The authors would like to thank the members of the Zhang lab, specifically Maxwell Shulman, for insightful discussions and comments to improve the manuscript and figures. Due to space limitation, we apologize for other outstanding studies not summarized or cited in this review.

Conflicts of Interest: The authors declare no conflict of interest. 


\section{References}

1. Hammarlund, E.U.; Flashman, E.; Mohlin, S.; Licausi, F. Oxygen-sensing mechanisms across eukaryotic kingdoms and their roles in complex multicellularity. Science 2020, 370, 6515. [CrossRef]

2. Zhang, Q.; Yan, Q.; Yang, H.; Wei, W. Oxygen sensing and adaptability won the 2019 Nobel Prize in Physiology or medicine. Genes Dis. 2019, 6, 328-332. [CrossRef]

3. Henley, S.J.; Ward, E.M.; Scott, S.; Ma, J.; Anderson, R.N.; Firth, A.U.; Thomas, C.C.; Islami, F.; Weir, H.K.; Lewis, D.R. Annual Report to the Nation on the Status of Cancer, part I: National cancer statistics. Cancer 2020, 126, 2225-2249. [CrossRef]

4. Vaupel, P.; Mayer, A. Hypoxia in cancer: Significance and impact on clinical outcome. Cancer Metastasis Rev. 2007, 26, 225-239. [CrossRef]

5. Muz, B.; de la Puente, P.; Azab, F.; Azab, A.K. The role of hypoxia in cancer progression, angiogenesis, metastasis, and resistance to therapy. Hypoxia 2015, 3, 83. [CrossRef] [PubMed]

6. Vaupel, P.; Höckel, M.; Mayer, A. Detection and characterization of tumor hypoxia using $\mathrm{pO}_{2}$ histography. Antioxid. Redox Signal. 2007, 9, 1221-1236. [CrossRef]

7. Bristow, R.G.; Hill, R.P. Hypoxia and metabolism. Hypoxia, DNA repair and genetic instability. Nat. Rev. Cancer 2008, 8, 180-192. [CrossRef] [PubMed]

8. Butturini, E.; Carcereri de Prati, A.; Boriero, D.; Mariotto, S. Tumor dormancy and interplay with hypoxic tumor microenvironment. Int. J. Mol. Sci. 2019, 20, 4305. [CrossRef] [PubMed]

9. Wang, G.L.; Semenza, G.L. Purification and characterization of hypoxia-inducible factor 1. J. Biol. Chem. 1995, $270,1230-1237$. [CrossRef]

10. Wang, G.L.; Jiang, B.H.; Rue, E.A.; Semenza, G.L. Hypoxia-inducible factor 1 is a basic-helix-loop-helix-PAS heterodimer regulated by cellular $\mathrm{O}_{2}$ tension. Proc. Natl. Acad. Sci. USA 1995, 92, 5510-5514. [CrossRef]

11. Schödel, J.; Ratcliffe, P.J. Mechanisms of hypoxia signalling: New implications for nephrology. Nat. Rev. Nephrol. 2019, 15, 641-659. [CrossRef]

12. Schofield, C.J.; Ratcliffe, P.J. Oxygen sensing by HIF hydroxylases. Nat. Rev. Mol. Cell Biol. 2004, 5, 343-354. [CrossRef]

13. Cockman, M.E.; Masson, N.; Mole, D.R.; Jaakkola, P.; Chang, G.W.; Clifford, S.C.; Maher, E.R.; Pugh, C.W.; Ratcliffe, P.J.; Maxwell, P.H. Hypoxia inducible factor- $\alpha$ binding and ubiquitylation by the von Hippel-Lindau tumor suppressor protein. J. Biol. Chem. 2000, 275, 25733-25741. [CrossRef] [PubMed]

14. Losman, J.A.; Kaelin, W.G., Jr. What a difference a hydroxyl makes: Mutant IDH, (R)-2-hydroxyglutarate, and cancer. Genes Dev. 2013, 27, 836-852. [CrossRef] [PubMed]

15. Losman, J.-A.; Koivunen, P.; Kaelin, W.G. 2-Oxoglutarate-dependent dioxygenases in cancer. Nat. Rev. Cancer 2020, 20, 710-726. [CrossRef]

16. Bayer, C.; Vaupel, P. Acute versus chronic hypoxia in tumors. Strahlenther. Onkol. 2012, 188, 616-627. [CrossRef] [PubMed]

17. Pettersen, E. Radiation-modifying effect of oxygen in synchronized cells pre-treated with acute or prolonged hypoxia. Int. J. Radiat. Biol. 1996, 70, 319-326. [CrossRef]

18. Holmquist-Mengelbier, L.; Fredlund, E.; Löfstedt, T.; Noguera, R.; Navarro, S.; Nilsson, H.; Pietras, A.; Vallon-Christersson, J.; Borg, Å.; Gradin, K. Recruitment of HIF- $1 \alpha$ and HIF- $2 \alpha$ to common target genes is differentially regulated in neuroblastoma: HIF-2 $\alpha$ promotes an aggressive phenotype. Cancer Cell 2006, 10, 413-423. [CrossRef]

19. Godet, I.; Shin, Y.J.; Ju, J.A.; Ye, I.C.; Wang, G.; Gilkes, D.M. Fate-mapping post-hypoxic tumor cells reveals a ROS-resistant phenotype that promotes metastasis. Nat. Commun. 2019, 10, 1-18. [CrossRef]

20. Alqawi, O.; Wang, H.P.; Espiritu, M.; Singh, G. Chronic hypoxia promotes an aggressive phenotype in rat prostate cancer cells. Free Radic. Res. 2007, 41, 788-797. [CrossRef]

21. Pires, I.M.; Bencokova, Z.; Milani, M.; Folkes, L.K.; Li, J.-L.; Stratford, M.R.; Harris, A.L.; Hammond, E.M. Effects of acute versus chronic hypoxia on DNA damage responses and genomic instability. Cancer Res. 2010, 70, 925-935. [CrossRef]

22. Tafani, M.; Pucci, B.; Russo, A.; Schito, L.; Pellegrini, L.; Perrone, G.A.; Villanova, L.; Salvatori, L.; Ravenna, L.; Petrangeli, E. Modulators of HIF1 $\alpha$ and NFkB in cancer treatment: Is it a rational approach for controlling malignant progression? Front. Pharmacol. 2013, 4, 13. [CrossRef]

23. Reynolds, T.Y.; Rockwell, S.; Glazer, P.M. Genetic instability induced by the tumor microenvironment. Cancer Res. 1996, 56, 5754-5757. [PubMed]

24. Papp-Szabó, E.; Josephy, P.D.; Coomber, B.L. Microenvironmental influences on mutagenesis in mammary epithelial cells. Int. J. Cancer 2005, 116, 679-685. [CrossRef] [PubMed]

25. Yuan, J.; Narayanan, L.; Rockwell, S.; Glazer, P.M. Diminished DNA repair and elevated mutagenesis in mammalian cells exposed to hypoxia and low pH. Cancer Res. 2000, 60, 4372-4376.

26. Coquelle, A.; Rozier, L.; Dutrillaux, B.; Debatisse, M. Induction of multiple double-strand breaks within an hsr by meganucleaseISceI expression or fragile site activation leads to formation of double minutes and other chromosomal rearrangements. Oncogene 2002, 21, 7671-7679. [CrossRef] [PubMed]

27. Cam, H.; Easton, J.B.; High, A.; Houghton, P.J. mTORC1 signaling under hypoxic conditions is controlled by ATM-dependent phosphorylation of HIF-1 $\alpha$. Mol. Cell 2010, 40, 509-520. [CrossRef]

28. Freiberg, R.A.; Hammond, E.M.; Dorie, M.J.; Welford, S.M.; Giaccia, A.J. DNA damage during reoxygenation elicits a Chk2dependent checkpoint response. Mol. Cell Biol. 2006, 26, 1598-1609. [CrossRef] [PubMed] 
29. Guzy, R.D.; Hoyos, B.; Robin, E.; Chen, H.; Liu, L.; Mansfield, K.D.; Simon, M.C.; Hammerling, U.; Schumacker, P.T. Mitochondrial complex III is required for hypoxia-induced ROS production and cellular oxygen sensing. Cell Metab. 2005, 1, 401-408. [CrossRef] [PubMed]

30. Nelson, D.A.; Tan, T.-T.; Rabson, A.B.; Anderson, D.; Degenhardt, K.; White, E. Hypoxia and defective apoptosis drive genomic instability and tumorigenesis. Genes Dev. 2004, 18, 2095-2107. [CrossRef]

31. Aparicio, T.; Baer, R.; Gautier, J. DNA double-strand break repair pathway choice and cancer. DNA Repair 2014, 19, 169-175. [CrossRef]

32. Dynan, W.S.; Yoo, S. Interaction of Ku protein and DNA-dependent protein kinase catalytic subunit with nucleic acids. Nucleic Acids Res. 1998, 26, 1551-1559. [CrossRef]

33. Mihaylova, V.T.; Bindra, R.S.; Yuan, J.; Campisi, D.; Narayanan, L.; Jensen, R.; Giordano, F.; Johnson, R.S.; Rockwell, S.; Glazer, P.M. Decreased expression of the DNA mismatch repair gene Mlh1 under hypoxic stress in mammalian cells. Mol. Cell. Biol. 2003, 23, 3265-3273. [CrossRef] [PubMed]

34. Bindra, R.S.; Gibson, S.L.; Meng, A.; Westermark, U.; Jasin, M.; Pierce, A.J.; Bristow, R.G.; Classon, M.K.; Glazer, P.M. Hypoxiainduced down-regulation of BRCA1 expression by E2Fs. Cancer Res. 2005, 65, 11597-11604. [CrossRef]

35. Bindra, R.S.; Glazer, P.M. Co-repression of mismatch repair gene expression by hypoxia in cancer cells: Role of the Myc/Max network. Cancer Lett. 2007, 252, 93-103. [CrossRef]

36. Bindra, R.; Glazer, P. Repression of RAD51 gene expression by E2F4/p130 complexes in hypoxia. Oncogene 2007, 26, 2048-2057. [CrossRef] [PubMed]

37. Zheng, F.; Zhang, Y.; Chen, S.; Weng, X.; Rao, Y.; Fang, H. Mechanism and current progress of Poly ADP-ribose polymerase (PARP) inhibitors in the treatment of ovarian cancer. Biomed. Pharmacother. 2020, 123, 109661. [CrossRef]

38. Kaplan, A.R.; Glazer, P.M. Impact of hypoxia on DNA repair and genome integrity. Mutagenesis 2020, 35, 61-68. [CrossRef] [PubMed]

39. Young, S.; Marshall, R.; Hill, R. Hypoxia induces DNA overreplication and enhances metastatic potential of murine tumor cells. Proc. Natl. Acad. Sci. USA 1988, 85, 9533-9537. [CrossRef] [PubMed]

40. Miao, Z.-F.; Zhao, T.-T.; Wang, Z.-N.; Xu, Y.-Y.; Mao, X.-Y.; Wu, J.-H.; Liu, X.-Y.; Xu, H.; You, Y.; Xu, H.-M. Influence of different hypoxia models on metastatic potential of SGC-7901 gastric cancer cells. Tumor Biol. 2014, 35, 6801-6808. [CrossRef]

41. Cairns, R.A.; Hill, R.P. Acute hypoxia enhances spontaneous lymph node metastasis in an orthotopic murine model of human cervical carcinoma. Cancer Res. 2004, 64, 2054-2061. [CrossRef] [PubMed]

42. Rofstad, E.K.; Gaustad, J.V.; Egeland, T.A.; Mathiesen, B.; Galappathi, K. Tumors exposed to acute cyclic hypoxic stress show enhanced angiogenesis, perfusion and metastatic dissemination. Int. J. Cancer 2010, 127, 1535-1546. [CrossRef] [PubMed]

43. Walsh, J.C.; Lebedev, A.; Aten, E.; Madsen, K.; Marciano, L.; Kolb, H.C. The clinical importance of assessing tumor hypoxia: Relationship of tumor hypoxia to prognosis and therapeutic opportunities. Antioxid. Redox Signal. 2014, 21, 1516-1554. [CrossRef] [PubMed]

44. Chan, D.A.; Giaccia, A.J. Hypoxia, gene expression, and metastasis. Cancer Metastasis Rev. 2007, 26, 333-339. [CrossRef] [PubMed]

45. Erler, J.T.; Giaccia, A.J. Lysyl oxidase mediates hypoxic control of metastasis. Cancer Res. 2006, 66, 10238-10241. [CrossRef]

46. Muz, B.; De La Puente, P.; Azab, F.; Ghobrial, I.M.; Azab, A.K. Hypoxia promotes dissemination and colonization in new bone marrow niches in Waldenström macroglobulinemia. Mol. Cancer Res. 2015, 13, 263-272. [CrossRef]

47. Fluegen, G.; Avivar-Valderas, A.; Wang, Y.; Padgen, M.R.; Williams, J.K.; Nobre, A.R.; Calvo, V.; Cheung, J.F.; Bravo-Cordero, J.J.; Entenberg, D. Phenotypic heterogeneity of disseminated tumour cells is preset by primary tumour hypoxic microenvironments. Nat. Cell Biol. 2017, 19, 120-132. [CrossRef] [PubMed]

48. Chen, A.; Sceneay, J.; Gödde, N.; Kinwel, T.; Ham, S.; Thompson, E.W.; Humbert, P.O.; Möller, A. Intermittent hypoxia induces a metastatic phenotype in breast cancer. Oncogene 2018, 37, 4214-4225. [CrossRef]

49. Muinao, T.; Boruah, H.P.D.; Pal, M. Diagnostic and Prognostic Biomarkers in ovarian cancer and the potential roles of cancer stem cells-An updated review. Exp. Cell Res. 2018, 362, 1-10. [CrossRef] [PubMed]

50. Nguyen, P.H.; Giraud, J.; Chambonnier, L.; Dubus, P.; Wittkop, L.; Belleannée, G.; Collet, D.; Soubeyran, I.; Evrard, S.; Rousseau, B. Characterization of biomarkers of tumorigenic and chemoresistant cancer stem cells in human gastric carcinoma. Clin. Cancer Res. 2017, 23, 1586-1597. [CrossRef]

51. Corro, C.; Moch, H. Biomarker discovery for renal cancer stem cells. J. Pathol. Clin. Res. 2018, 4, 3-18. [CrossRef] [PubMed]

52. Yang, F.; Xu, J.; Tang, L.; Guan, X. Breast cancer stem cell: The roles and therapeutic implications. Cell. Mol. Life Sci. 2017, 74, 951-966. [CrossRef] [PubMed]

53. Smit, J.K.; Faber, H.; Niemantsverdriet, M.; Baanstra, M.; Bussink, J.; Hollema, H.; van Os, R.P.; Plukker, J.T.M.; Coppes, R.P. Prediction of response to radiotherapy in the treatment of esophageal cancer using stem cell markers. Radiother. Oncol. 2013, 107, 434-441. [CrossRef] [PubMed]

54. Singh, S.K.; Hawkins, C.; Clarke, I.D.; Squire, J.A.; Bayani, J.; Hide, T.; Henkelman, R.M.; Cusimano, M.D.; Dirks, P.B. Identification of human brain tumour initiating cells. Nature 2004, 432, 396-401. [CrossRef] [PubMed]

55. Li, C.; Heidt, D.G.; Dalerba, P.; Burant, C.F.; Zhang, L.; Adsay, V.; Wicha, M.; Clarke, M.F.; Simeone, D.M. Identification of pancreatic cancer stem cells. Cancer Res. 2007, 67, 1030-1037. [CrossRef]

56. Eramo, A.; Lotti, F.; Sette, G.; Pilozzi, E.; Biffoni, M.; Di Virgilio, A.; Conticello, C.; Ruco, L.; Peschle, C.; De Maria, R. Identification and expansion of the tumorigenic lung cancer stem cell population. Cell Death Differ. 2008, 15, 504-514. [CrossRef] 
57. Ricci-Vitiani, L.; Lombardi, D.G.; Pilozzi, E.; Biffoni, M.; Todaro, M.; Peschle, C.; De Maria, R. Identification and expansion of human colon-cancer-initiating cells. Nature 2007, 445, 111-115. [CrossRef]

58. Zomer, A.; Ellenbroek, S.I.J.; Ritsma, L.; Beerling, E.; Vrisekoop, N.; Van Rheenen, J. Brief report: Intravital imaging of cancer stem cell plasticity in mammary tumors. Stem Cells 2013, 31, 602-606. [CrossRef] [PubMed]

59. Jögi, A.; Øra, I.; Nilsson, H.; Lindeheim, Å.; Makino, Y.; Poellinger, L.; Axelson, H.; Påhlman, S. Hypoxia alters gene expression in human neuroblastoma cells toward an immature and neural crest-like phenotype. Proc. Natl. Acad. Sci. USA 2002, 99, 7021-7026. [CrossRef]

60. Helczynska, K.; Kronblad, Å.; Jögi, A.; Nilsson, E.; Beckman, S.; Landberg, G.; Påhlman, S. Hypoxia promotes a dedifferentiated phenotype in ductal breast carcinoma in situ. Cancer Res. 2003, 63, 1441-1444.

61. Chang, S.; Park, B.; Choi, K.; Moon, Y.; Lee, H.Y.; Park, H. Hypoxic reprograming of H3K27me3 and H3K4me3 at the INK 4A locus. FEBS Lett. 2016, 590, 3407-3415. [CrossRef]

62. Mathieu, J.; Zhang, Z.; Zhou, W.; Wang, A.J.; Heddleston, J.M.; Pinna, C.M.; Hubaud, A.; Stadler, B.; Choi, M.; Bar, M. HIF induces human embryonic stem cell markers in cancer cells. Cancer Res. 2011, 71, 4640-4652. [CrossRef]

63. Eastham, A.M.; Spencer, H.; Soncin, F.; Ritson, S.; Merry, C.L.; Stern, P.L.; Ward, C.M. Epithelial-mesenchymal transition events during human embryonic stem cell differentiation. Cancer Res. 2007, 67, 11254-11262. [CrossRef] [PubMed]

64. Mani, S.A.; Guo, W.; Liao, M.-J.; Eaton, E.N.; Ayyanan, A.; Zhou, A.Y.; Brooks, M.; Reinhard, F.; Zhang, C.C.; Shipitsin, M. The epithelial-mesenchymal transition generates cells with properties of stem cells. Cell 2008, 133, 704-715. [CrossRef] [PubMed]

65. Shibue, T.; Weinberg, R.A. EMT, CSCs, and drug resistance: The mechanistic link and clinical implications. Nat. Rev. Clin. Oncol. 2017, 14, 611. [CrossRef]

66. Da Silva, S.D.; Morand, G.B.; Alobaid, F.A.; Hier, M.P.; Mlynarek, A.M.; Alaoui-Jamali, M.A.; Kowalski, L.P. Epithelialmesenchymal transition (EMT) markers have prognostic impact in multiple primary oral squamous cell carcinoma. Clin. Exp. Metastasis 2015, 32, 55-63. [CrossRef] [PubMed]

67. Azab, A.K.; Hu, J.; Quang, P.; Azab, F.; Pitsillides, C.; Awwad, R.; Thompson, B.; Maiso, P.; Sun, J.D.; Hart, C.P. Hypoxia promotes dissemination of multiple myeloma through acquisition of epithelial to mesenchymal transition-like features. Blood 2012, 119, 5782-5794. [CrossRef] [PubMed]

68. Thiery, J.P.; Acloque, H.; Huang, R.Y.; Nieto, M.A. Epithelial-mesenchymal transitions in development and disease. Cell 2009, 139, 871-890. [CrossRef] [PubMed]

69. Renaud, S.; Guenot, D.; Falcoz, P.-E.; Massard, G.; Beau-Faller, M. Role of hypoxia in epithelial-to-mesenchymal transition (EMT) in non-small cell lung cancer (NSCLC). Eur. Respir. J. 2014, 44, 814.

70. Cheng, Z.-X.; Sun, B.; Wang, S.-J.; Gao, Y.; Zhang, Y.-M.; Zhou, H.-X.; Jia, G.; Wang, Y.-W.; Kong, R.; Pan, S.-H. Nuclear factor-kbdependent epithelial to mesenchymal transition induced by HIF-1 $\alpha$ activation in pancreatic cancer cells under hypoxic conditions. PLoS ONE 2011, 6, e23752. [CrossRef]

71. Cheng, Z.-X.; Wang, D.-W.; Liu, T.; Liu, W.-X.; Xia, W.-B.; Xu, J.; Zhang, Y.-H.; Qu, Y.-K.; Guo, L.-Q.; Ding, L. Effects of the HIF-1 $\alpha$ and NF- $\mathrm{kB}$ loop on epithelial-mesenchymal transition and chemoresistance induced by hypoxia in pancreatic cancer cells. Oncol. Rep. 2014, 31, 1891-1898. [CrossRef]

72. Li, Y.; Wang, Y.; Li, L.; Kong, R.; Pan, S.; Ji, L.; Liu, H.; Chen, H.; Sun, B. Hyperoside induces apoptosis and inhibits growth in pancreatic cancer via Bcl-2 family and NF-кB signaling pathway both in vitro and in vivo. Tumor Biol. 2016, 37, 7345-7355. [CrossRef] [PubMed]

73. Arner, E.N.; Du, W.; Brekken, R.A. Behind the Wheel of Epithelial Plasticity in KRAS-Driven Cancers. Front. Oncol. 2019, 9 , 1049. [CrossRef]

74. Buck, E.; Eyzaguirre, A.; Barr, S.; Thompson, S.; Sennello, R.; Young, D.; Iwata, K.K.; Gibson, N.W.; Cagnoni, P.; Haley, J.D. Loss of homotypic cell adhesion by epithelial-mesenchymal transition or mutation limits sensitivity to epidermal growth factor receptor inhibition. Mol. Cancer Ther. 2007, 6, 532-541. [CrossRef] [PubMed]

75. Shrader, M.; Pino, M.S.; Brown, G.; Black, P.; Adam, L.; Bar-Eli, M.; Dinney, C.P.; McConkey, D.J. Molecular correlates of gefitinib responsiveness in human bladder cancer cells. Mol. Cancer Ther. 2007, 6, 277-285. [CrossRef] [PubMed]

76. Frederiksen, L.J.; Siemens, D.R.; Heaton, J.P.; Maxwell, L.R.; Adams, M.A.; Graham, C.H. Hypoxia induced resistance to doxorubicin in prostate cancer cells is inhibited by low concentrations of glyceryl trinitrate. J. Urol. 2003, 170, $1003-1007$. [CrossRef] [PubMed]

77. Witta, S.E.; Gemmill, R.M.; Hirsch, F.R.; Coldren, C.D.; Hedman, K.; Ravdel, L.; Helfrich, B.; Dziadziuszko, R.; Chan, D.C.; Sugita, M. Restoring E-cadherin expression increases sensitivity to epidermal growth factor receptor inhibitors in lung cancer cell lines. Cancer Res. 2006, 66, 944-950. [CrossRef] [PubMed]

78. Kudo-Saito, C.; Shirako, H.; Takeuchi, T.; Kawakami, Y. Cancer metastasis is accelerated through immunosuppression during Snail-induced EMT of cancer cells. Cancer Cell 2009, 15, 195-206. [CrossRef] [PubMed]

79. Kurrey, N.K.; Jalgaonkar, S.P.; Joglekar, A.V.; Ghanate, A.D.; Chaskar, P.D.; Doiphode, R.Y.; Bapat, S.A. Snail and slug mediate radioresistance and chemoresistance by antagonizing p53-mediated apoptosis and acquiring a stem-like phenotype in ovarian cancer cells. Stem Cells 2009, 27, 2059-2068. [CrossRef] [PubMed]

80. Chen, P.; Hsu, W.-H.; Han, J.; Xia, Y.; DePinho, R.A. Cancer Stemness Meets Immunity: From Mechanism to Therapy. Cell Rep. 2021, 34, 108597. [CrossRef] 
81. Miranda, A.; Hamilton, P.T.; Zhang, A.W.; Pattnaik, S.; Becht, E.; Mezheyeuski, A.; Bruun, J.; Micke, P.; de Reynies, A.; Nelson, B.H. Cancer stemness, intratumoral heterogeneity, and immune response across cancers. Proc. Natl. Acad. Sci. USA 2019, 116, 9020-9029. [CrossRef]

82. Hou, Y.-C.; Chao, Y.-J.; Hsieh, M.-H.; Tung, H.-L.; Wang, H.-C.; Shan, Y.-S. Low CD8 ${ }^{+}$T cell infiltration and high PD-L1 expression are associated with level of $\mathrm{CD} 44^{+} / \mathrm{CD} 133^{+}$cancer stem cells and predict an unfavorable prognosis in pancreatic cancer. Cancers 2019, 11, 541. [CrossRef] [PubMed]

83. Phi, L.T.H.; Sari, I.N.; Yang, Y.-G.; Lee, S.-H.; Jun, N.; Kim, K.S.; Lee, Y.K.; Kwon, H.Y. Cancer stem cells (CSCs) in drug resistance and their therapeutic implications in cancer treatment. Stem Cells Int. 2018, 2018, 5416923. [CrossRef] [PubMed]

84. Thews, O.; Riemann, A.; Nowak, M.; Gekle, M. Impact of hypoxia-related tumor acidosis on cytotoxicity of different chemotherapeutic drugs in vitro and in vivo. In Oxygen Transport to Tissue XXXVI; Springer: Berlin/Heidelberg, Germany, 2014; pp. 51-58.

85. Graham, K.; Unger, E. Overcoming tumor hypoxia as a barrier to radiotherapy, chemotherapy and immunotherapy in cancer treatment. Int. J. Nanomed. 2018, 13, 6049. [CrossRef] [PubMed]

86. Roizin-towle, L.; Hall, E.J. The effect of bleomycin on aerated and hypoxic cells in vitro, in combination with irradiation. Int. J. Radiat. Oncol. Biol. Phys. 1979, 5, 1491-1494.

87. Conley, S.J.; Gheordunescu, E.; Kakarala, P.; Newman, B.; Korkaya, H.; Heath, A.N.; Clouthier, S.G.; Wicha, M.S. Antiangiogenic agents increase breast cancer stem cells via the generation of tumor hypoxia. Proc. Natl. Acad. Sci. USA 2012, 109, $2784-2789$. [CrossRef]

88. Li, D.; Zhou, L.; Huang, J.; Xiao, X. Effect of multidrug resistance 1/P-glycoprotein on the hypoxia-induced multidrug resistance of human laryngeal cancer cells. Oncol. Lett. 2016, 12, 1569-1574. [CrossRef]

89. Flamant, L.; Roegiers, E.; Pierre, M.; Hayez, A.; Sterpin, C.; De Backer, O.; Arnould, T.; Poumay, Y.; Michiels, C. TMEM45A is essential for hypoxia-induced chemoresistance in breast and liver cancer cells. BMC Cancer 2012, 12, 391. [CrossRef]

90. Mottram, J. A factor of importance in the radio sensitivity of tumours. Br. J. Radiol. 1936, 9, 606-614. [CrossRef]

91. Evans, S.M.; Koch, C.J. Prognostic significance of tumor oxygenation in humans. Cancer Lett. 2003, 195, 1-16. [CrossRef]

92. Chaplin, D.; Durand, R.; Olive, P. Acute hypoxia in tumors: Implications for modifiers of radiation effects. Int. J. Radiat. Oncol. Biol. Phys. 1986, 12, 1279-1282. [CrossRef]

93. Hsieh, C.-H.; Lee, C.-H.; Liang, J.-A.; Yu, C.-Y.; Shyu, W.-C. Cycling hypoxia increases U87 glioma cell radioresistance via ROS induced higher and long-term HIF-1 signal transduction activity. Oncol. Rep. 2010, 24, 1629-1636. [CrossRef] [PubMed]

94. Kato, Y.; Yashiro, M.; Fuyuhiro, Y.; Kashiwagi, S.; Matsuoka, J.; Hirakawa, T.; Noda, S.; Aomatsu, N.; Hasegawa, T.; Matsuzaki, T. Effects of acute and chronic hypoxia on the radiosensitivity of gastric and esophageal cancer cells. Anticancer. Res. 2011, 31, 3369-3375. [PubMed]

95. Zheng, Y.; Liu, L.; Chen, C.; Ming, P.; Huang, Q.; Li, C.; Cao, D.; Xu, X.; Ge, W. The extracellular vesicles secreted by lung cancer cells in radiation therapy promote endothelial cell angiogenesis by transferring miR-23a. PeerJ 2017, 5, e3627. [CrossRef] [PubMed]

96. Haider, S.; McIntyre, A.; van Stiphout, R.G.; Winchester, L.M.; Wigfield, S.; Harris, A.L.; Buffa, F.M. Genomic alterations underlie a pan-cancer metabolic shift associated with tumour hypoxia. Genome Biol. 2016, 17, 1-17. [CrossRef] [PubMed]

97. McIntyre, A.; Harris, A.L. Metabolic and hypoxic adaptation to anti-angiogenic therapy: A target for induced essentiality. EMBO Mol. Med. 2015, 7, 368-379. [CrossRef]

98. Zhang, J.; Pavlova, N.N.; Thompson, C.B. Cancer cell metabolism: The essential role of the nonessential amino acid, glutamine. EMBO J. 2017, 36, 1302-1315. [CrossRef]

99. Chang, S.; Yim, S.; Park, H. The cancer driver genes IDH1/2, JARID1C/KDM5C, and UTX/KDM6A: Crosstalk between histone demethylation and hypoxic reprogramming in cancer metabolism. Exp. Mol. Med. 2019, 51, 66. [CrossRef]

100. Pilon-Thomas, S.; Kodumudi, K.N.; El-Kenawi, A.E.; Russell, S.; Weber, A.M.; Luddy, K.; Damaghi, M.; Wojtkowiak, J.W.; Mulé, J.J.; Ibrahim-Hashim, A. Neutralization of tumor acidity improves antitumor responses to immunotherapy. Cancer Res. 2016, 76, 1381-1390. [CrossRef]

101. Hatfield, S.M.; Sitkovsky, M. A2A adenosine receptor antagonists to weaken the hypoxia-HIF-1 $\alpha$ driven immunosuppression and improve immunotherapies of cancer. Curr. Opin. Pharmacol. 2016, 29, 90-96. [CrossRef]

102. Kathagen, A.; Schulte, A.; Balcke, G.; Phillips, H.S.; Martens, T.; Matschke, J.; Günther, H.S.; Soriano, R.; Modrusan, Z.; Sandmann, T. Hypoxia and oxygenation induce a metabolic switch between pentose phosphate pathway and glycolysis in glioma stem-like cells. Acta Neuropathol. 2013, 126, 763-780. [CrossRef]

103. Kathagen-Buhmann, A.; Schulte, A.; Weller, J.; Holz, M.; Herold-Mende, C.; Glass, R.; Lamszus, K. Glycolysis and the pentose phosphate pathway are differentially associated with the dichotomous regulation of glioblastoma cell migration versus proliferation. Neuro Oncol. 2016, 18, 1219-1229. [CrossRef]

104. Ashton, T.M.; McKenna, W.G.; Kunz-Schughart, L.A.; Higgins, G.S. Oxidative phosphorylation as an emerging target in cancer therapy. Clin. Cancer Res. 2018, 24, 2482-2490. [CrossRef]

105. Jin, X.; Demere, Z.; Nair, K.; Ali, A.; Ferraro, G.B.; Natoli, T.; Deik, A.; Petronio, L.; Tang, A.A.; Zhu, C. A metastasis map of human cancer cell lines. Nature 2020, 588, 331-336. [CrossRef]

106. Noman, M.Z.; Hasmim, M.; Messai, Y.; Terry, S.; Kieda, C.; Janji, B.; Chouaib, S. Hypoxia: A key player in antitumor immune response. A review in the theme: Cellular responses to hypoxia. Am. J. Physiol. Cell Physiol. 2015, 309, C569-C579. [CrossRef] 
107. Briggs, K.J.; Koivunen, P.; Cao, S.; Backus, K.M.; Olenchock, B.A.; Patel, H.; Zhang, Q.; Signoretti, S.; Gerfen, G.J.; Richardson, A.L. Paracrine induction of HIF by glutamate in breast cancer: EglN1 senses cysteine. Cell 2016, 166, 126-139. [CrossRef]

108. Jiao, M.; Nan, K.-J. Activation of PI3 kinase/Akt/HIF-1 $\alpha$ pathway contributes to hypoxia-induced epithelial-mesenchymal transition and chemoresistance in hepatocellular carcinoma. Int. J. Oncol. 2012, 40, 461-468.

109. Jögi, A.; Ehinger, A.; Hartman, L.; Alkner, S. Expression of HIF-1 $\alpha$ is related to a poor prognosis and tamoxifen resistance in contralateral breast cancer. PLoS ONE 2019, 14, e0226150. [CrossRef] [PubMed]

110. Klaus, A.; Fathi, O.; Tatjana, T.-W.; Bruno, N.; Oskar, K. Expression of hypoxia-associated protein HIF-1 $\alpha$ in follicular thyroid cancer is associated with distant metastasis. Pathol. Oncol. Res. 2018, 24, 289-296. [CrossRef] [PubMed]

111. Shen, W.; Li, H.; Liu, L.; Cheng, J. Expression levels of PTEN, HIF-1alpha, and VEGF as prognostic factors in ovarian cancer. Eur. Rev. Med. Pharmacol. Sci. 2017, 21, 2596-2603. [PubMed]

112. Lin, C.-S.; Liu, T.-C.; Lee, M.-T.; Yang, S.-F.; Tsao, T.C.-Y. Independent prognostic value of hypoxia-inducible factor 1-alpha expression in small cell lung cancer. Int. J. Med. Sci. 2017, 14, 785. [CrossRef]

113. Bottini, A.; Harris, A.L.; Fox, S.B. Hypoxia-Inducible Factor-1AExpression Predicts a Poor Response to Primary ChemoendocrineTherapy and Disease-Free Survival in Primary Human Breast Cancer. Clin. Cancer Res. 2006, $2006,15$.

114. Semenza, G.L. Oxygen sensing, hypoxia-inducible factors, and disease pathophysiology. Annu. Rev. Pathol. Mech. Dis. 2014, 9, 47-71. [CrossRef]

115. Schödel, J.; Oikonomopoulos, S.; Ragoussis, J.; Pugh, C.W.; Ratcliffe, P.J.; Mole, D.R. High-resolution genome-wide mapping of HIF-binding sites by ChIP-seq. Blood J. Am. Soc. Hematol. 2011, 117, e207-e217. [CrossRef]

116. Kelly, B.D.; Hackett, S.F.; Hirota, K.; Oshima, Y.; Cai, Z.; Berg-Dixon, S.; Rowan, A.; Yan, Z.; Campochiaro, P.A.; Semenza, G.L. Cell type-specific regulation of angiogenic growth factor gene expression and induction of angiogenesis in nonischemic tissue by a constitutively active form of hypoxia-inducible factor 1. Circ. Res. 2003, 93, 1074-1081. [CrossRef]

117. Wong, C.C.-L.; Gilkes, D.M.; Zhang, H.; Chen, J.; Wei, H.; Chaturvedi, P.; Fraley, S.I.; Wong, C.-M.; Khoo, U.-S.; Ng, I.O.-L. Hypoxia-inducible factor 1 is a master regulator of breast cancer metastatic niche formation. Proc. Natl. Acad. Sci. USA 2011, 108, 16369-16374. [CrossRef] [PubMed]

118. Dang, C.V.; Kim, J.-W.; Gao, P.; Yustein, J. The interplay between MYC and HIF in cancer. Nat. Rev. Cancer 2008, 8, 51-56. [CrossRef] [PubMed]

119. Gordan, J.D.; Thompson, C.B.; Simon, M.C. HIF and c-Myc: Sibling rivals for control of cancer cell metabolism and proliferation. Cancer Cell 2007, 12, 108-113. [CrossRef] [PubMed]

120. Semenza, G.L. Hypoxia-inducible factors: Mediators of cancer progression and targets for cancer therapy. Trends Pharmacol. Sci. 2012, 33, 207-214. [CrossRef] [PubMed]

121. Lee, K.E.; Simon, M.C. From stem cells to cancer stem cells: HIF takes the stage. Curr. Opin. Cell Biol. 2012, 24, 232-235. [CrossRef] [PubMed]

122. Yang, M.-H.; Wu, M.-Z.; Chiou, S.-H.; Chen, P.-M.; Chang, S.-Y.; Liu, C.-J.; Teng, S.-C.; Wu, K.-J. Direct regulation of TWIST by HIF-1 $\alpha$ promotes metastasis. Nat. Cell Biol. 2008, 10, 295-305. [CrossRef] [PubMed]

123. Chafe, S.C.; McDonald, P.C.; Saberi, S.; Nemirovsky, O.; Venkateswaran, G.; Burugu, S.; Gao, D.; Delaidelli, A.; Kyle, A.H.; Baker, J.H. Targeting hypoxia-induced carbonic anhydrase IX enhances immune-checkpoint blockade locally and systemically. Cancer Immunol. Res. 2019, 7, 1064-1078. [CrossRef]

124. Zhang, Q.; Bai, X.; Chen, W.; Ma, T.; Hu, Q.; Liang, C.; Xie, S.; Chen, C.; Hu, L.; Xu, S. Wnt/ $\beta$-catenin signaling enhances hypoxia-induced epithelial-mesenchymal transition in hepatocellular carcinoma via crosstalk with hif-1 $\alpha$ signaling. Carcinogenesis 2013, 34, 962-973. [CrossRef]

125. Erler, J.T.; Bennewith, K.L.; Nicolau, M.; Dornhöfer, N.; Kong, C.; Le, Q.-T.; Chi, J.-T.A.; Jeffrey, S.S.; Giaccia, A.J. Lysyl oxidase is essential for hypoxia-induced metastasis. Nature 2006, 440, 1222-1226. [CrossRef] [PubMed]

126. Saatci, O.; Kaymak, A.; Raza, U.; Ersan, P.G.; Akbulut, O.; Banister, C.E.; Sikirzhytski, V.; Tokat, U.M.; Aykut, G.; Ansari, S.A. Targeting lysyl oxidase (LOX) overcomes chemotherapy resistance in triple negative breast cancer. Nat. Commun. 2020, 11, 1-17. [CrossRef]

127. Moreno Roig, E.; Groot, A.J.; Yaromina, A.; Hendrickx, T.C.; Barbeau, L.M.; Giuranno, L.; Dams, G.; Ient, J.; Olivo Pimentel, V.; van Gisbergen, M.W. HIF-1 $\alpha$ and HIF-2 $\alpha$ Differently Regulate the Radiation Sensitivity of NSCLC Cells. Cells $2019,8,45$. [CrossRef] [PubMed]

128. Kim, W.Y.; Perera, S.; Zhou, B.; Carretero, J.; Yeh, J.J.; Heathcote, S.A.; Jackson, A.L.; Nikolinakos, P.; Ospina, B.; Naumov, G. HIF2 $\alpha$ cooperates with RAS to promote lung tumorigenesis in mice. J. Clin. Investig. 2009, 119, 2160-2170. [CrossRef]

129. Bishop, T.; Ratcliffe, P.J. HIF hydroxylase pathways in cardiovascular physiology and medicine. Circ. Res. 2015, 117, 65-79. [CrossRef]

130. Masson, N.; Ratcliffe, P.J. Hypoxia signaling pathways in cancer metabolism: The importance of co-selecting interconnected physiological pathways. Cancer Metab. 2014, 2, 1-17. [CrossRef]

131. Kapitsinou, P.P.; Liu, Q.; Unger, T.L.; Rha, J.; Davidoff, O.; Keith, B.; Epstein, J.A.; Moores, S.L.; Erickson-Miller, C.L.; Haase, V.H. Hepatic HIF-2 regulates erythropoietic responses to hypoxia in renal anemia. Blood J. Am. Soc. Hematol. 2010, 116, 3039-3048. [CrossRef]

132. Anderson, E.R.; Xue, X.; Shah, Y.M. Intestinal hypoxia-inducible factor- $2 \alpha(\mathrm{HIF}-2 \alpha)$ is critical for efficient erythropoiesis. J. Biol. Chem. 2011, 286, 19533-19540. [CrossRef] 
133. Gao, P.; Zhang, H.; Dinavahi, R.; Li, F.; Xiang, Y.; Raman, V.; Bhujwalla, Z.M.; Felsher, D.W.; Cheng, L.; Pevsner, J. HIF-dependent antitumorigenic effect of antioxidants in vivo. Cancer Cell 2007, 12, 230-238. [CrossRef]

134. Agani, F.; Jiang, B.-H. Oxygen-independent regulation of HIF-1: Novel involvement of PI3K/AKT/mTOR pathway in cancer. Curr. Cancer Drug Targets 2013, 13, 245-251. [CrossRef]

135. Lee, K.; Qian, D.Z.; Rey, S.; Wei, H.; Liu, J.O.; Semenza, G.L. Anthracycline chemotherapy inhibits HIF-1 transcriptional activity and tumor-induced mobilization of circulating angiogenic cells. Proc. Natl. Acad. Sci. USA 2009, 106, 2353-2358. [CrossRef]

136. Erler, J.T.; Bennewith, K.L.; Cox, T.R.; Lang, G.; Bird, D.; Koong, A.; Le, Q.-T.; Giaccia, A.J. Hypoxia-induced lysyl oxidase is a critical mediator of bone marrow cell recruitment to form the premetastatic niche. Cancer Cell 2009, 15, 35-44. [CrossRef]

137. Wu, X.; Qiao, B.; Liu, Q.; Zhang, W. Upregulation of extracellular matrix metalloproteinase inducer promotes hypoxia-induced epithelial-mesenchymal transition in esophageal cancer. Mol. Med. Rep. 2015, 12, 7419-7424. [CrossRef] [PubMed]

138. Zhang, H.; Wong, C.; Wei, H.; Gilkes, D.; Korangath, P.; Chaturvedi, P.; Schito, L.; Chen, J.; Krishnamachary, B.; Winnard, P.T. HIF-1-dependent expression of angiopoietin-like 4 and L1CAM mediates vascular metastasis of hypoxic breast cancer cells to the lungs. Oncogene 2012, 31, 1757-1770. [CrossRef]

139. Hanna, S.C.; Krishnan, B.; Bailey, S.T.; Moschos, S.J.; Kuan, P.-F.; Shimamura, T.; Osborne, L.D.; Siegel, M.B.; Duncan, L.M.; O'Brien, E.T. HIF1 $\alpha$ and HIF2 $\alpha$ independently activate SRC to promote melanoma metastases. J. Clin. Investig. 2013, 123, 2078-2093. [CrossRef] [PubMed]

140. Schito, L.; Rey, S.; Tafani, M.; Zhang, H.; Wong, C.C.-L.; Russo, A.; Russo, M.A.; Semenza, G.L. Hypoxia-inducible factor 1-dependent expression of platelet-derived growth factor B promotes lymphatic metastasis of hypoxic breast cancer cells. Proc. Natl. Acad. Sci. USA 2012, 109, E2707-E2716. [CrossRef] [PubMed]

141. Huang, R.; Zong, X. Aberrant cancer metabolism in epithelial-mesenchymal transition and cancer metastasis: Mechanisms in cancer progression. Crit. Rev. Oncol. Hematol. 2017, 115, 13-22. [CrossRef]

142. Dupuy, F.; Tabariès, S.; Andrzejewski, S.; Dong, Z.; Blagih, J.; Annis, M.G.; Omeroglu, A.; Gao, D.; Leung, S.; Amir, E. PDK1dependent metabolic reprogramming dictates metastatic potential in breast cancer. Cell Metab. 2015, 22, 577-589. [CrossRef] [PubMed]

143. Palazon, A.; Goldrath, A.W.; Nizet, V.; Johnson, R.S. HIF Transcription Factors, Inflammation, and Immunity. Immunity 2014, 41, 518-528. [CrossRef] [PubMed]

144. Li, J.; Wang, L.; Chen, X.; Li, L.; Li, Y.; Ping, Y.; Huang, L.; Yue, D.; Zhang, Z.; Wang, F. CD39/CD73 upregulation on myeloidderived suppressor cells via TGF- $\beta$-mTOR-HIF-1 signaling in patients with non-small cell lung cancer. Oncoimmunology 2017, 6 , e1320011. [CrossRef]

145. Noman, M.Z.; Desantis, G.; Janji, B.; Hasmim, M.; Karray, S.; Dessen, P.; Bronte, V.; Chouaib, S. PD-L1 is a novel direct target of HIF-1 $\alpha$, and its blockade under hypoxia enhanced MDSC-mediated T cell activation. J. Exp. Med. 2014, 211, 781-790. [CrossRef]

146. Samanta, D.; Gilkes, D.M.; Chaturvedi, P.; Xiang, L.; Semenza, G.L. Hypoxia-inducible factors are required for chemotherapy resistance of breast cancer stem cells. Proc. Natl. Acad. Sci. USA 2014, 111, E5429-E5438. [CrossRef] [PubMed]

147. Keith, B.; Simon, M.C. Hypoxia-inducible factors, stem cells, and cancer. Cell 2007, 129, 465-472. [CrossRef] [PubMed]

148. Takeuchi, M.; Kimura, S.; Kuroda, J.; Ashihara, E.; Kawatani, M.; Osada, H.; Umezawa, K.; Yasui, E.; Imoto, M.; Tsuruo, T. Glyoxalase-I is a novel target against Bcr-Abl+ leukemic cells acquiring stem-like characteristics in a hypoxic environment. Cell Death Differ. 2010, 17, 1211-1220. [CrossRef] [PubMed]

149. McMahon, S.; Charbonneau, M.; Grandmont, S.; Richard, D.E.; Dubois, C.M. Transforming growth factor $\beta 1$ induces hypoxiainducible factor-1 stabilization through selective inhibition of PHD2 expression. J. Biol. Chem. 2006, 281, 24171-24181. [CrossRef]

150. Deschoemaeker, S.; Di Conza, G.; Lilla, S.; Martín-Pérez, R.; Mennerich, D.; Boon, L.; Hendrikx, S.; Maddocks, O.D.; Marx, C.; Radhakrishnan, P. PHD 1 regulates p53-mediated colorectal cancer chemoresistance. EMBO Mol. Med. 2015, 7, 1350-1365. [CrossRef]

151. Hinohara, K.; Wu, H.-J.; Vigneau, S.; McDonald, T.O.; Igarashi, K.J.; Yamamoto, K.N.; Madsen, T.; Fassl, A.; Egri, S.B.; Papanastasiou, M. KDM5 histone demethylase activity links cellular transcriptomic heterogeneity to therapeutic resistance. Cancer Cell 2018, 34, 939-953.e939. [CrossRef]

152. Liu, X.; Zhang, S.-M.; McGeary, M.K.; Krykbaeva, I.; Lai, L.; Jansen, D.J.; Kales, S.C.; Simeonov, A.; Hall, M.D.; Kelly, D.P. KDM5B promotes drug resistance by regulating melanoma-propagating cell subpopulations. Mol. Cancer Ther. 2019, 18, 706-717. [CrossRef] [PubMed]

153. Chakraborty, A.A.; Laukka, T.; Myllykoski, M.; Ringel, A.E.; Booker, M.A.; Tolstorukov, M.Y.; Meng, Y.J.; Meier, S.R.; Jennings, R.B.; Creech, A.L.; et al. Histone demethylase KDM6A directly senses oxygen to control chromatin and cell fate. Science 2019, 363, 1217-1222. [CrossRef]

154. Hakimi, A.A.; Chen, Y.-B.; Wren, J.; Gonen, M.; Abdel-Wahab, O.; Heguy, A.; Liu, H.; Takeda, S.; Tickoo, S.K.; Reuter, V.E. Clinical and pathologic impact of select chromatin-modulating tumor suppressors in clear cell renal cell carcinoma. Eur. Urol. 2013, 63, 848-854. [CrossRef] [PubMed]

155. Gossage, L.; Murtaza, M.; Slatter, A.F.; Lichtenstein, C.P.; Warren, A.; Haynes, B.; Marass, F.; Roberts, I.; Shanahan, S.J.; Claas, A. Clinical and pathological impact of VHL, PBRM1, BAP1, SETD2, KDM6A, and JARID1c in clear cell renal cell carcinoma. Genes Chromos. Cancer 2014, 53, 38-51. [CrossRef] [PubMed]

156. Wang, L.; Shilatifard, A. UTX mutations in human cancer. Cancer Cell 2019, 35, 168-176. [CrossRef] 
157. Choi, H.J.; Park, J.H.; Park, M.; Won, H.Y.; Joo, H.s.; Lee, C.H.; Lee, J.Y.; Kong, G. UTX inhibits EMT-induced breast CSC properties by epigenetic repression of EMT genes in cooperation with LSD 1 and HDAC 1. EMBO Rep. 2015, 16, 1288-1298. [CrossRef]

158. Zhang, C.; Samanta, D.; Lu, H.; Bullen, J.W.; Zhang, H.; Chen, I.; He, X.; Semenza, G.L. Hypoxia induces the breast cancer stem cell phenotype by HIF-dependent and ALKBH5-mediated m6A-demethylation of NANOG mRNA. Proc. Natl. Acad. Sci. USA 2016, 113, E2047-E2056. [CrossRef]

159. Bartoszewska, S.; Collawn, J.F. Unfolded protein response (UPR) integrated signaling networks determine cell fate during hypoxia. Cell. Mol. Biol. Lett. 2020, 25, 1-20. [CrossRef]

160. Hetz, C. The unfolded protein response: Controlling cell fate decisions under ER stress and beyond. Nat. Rev. Mol. Cell Biol. 2012, 13, 89-102. [CrossRef]

161. Wouters, B.G.; Koritzinsky, M. Hypoxia signalling through mTOR and the unfolded protein response in cancer. Nat. Rev. Cancer 2008, 8, 851-864. [CrossRef]

162. Feng, Y.-X.; Jin, D.X.; Sokol, E.S.; Reinhardt, F.; Miller, D.H.; Gupta, P.B. Cancer-specific PERK signaling drives invasion and metastasis through CREB3L1. Nat. Commun. 2017, 8, 1-10. [CrossRef]

163. Rouschop, K.M.; Dubois, L.J.; Keulers, T.G.; van den Beucken, T.; Lambin, P.; Bussink, J.; van der Kogel, A.J.; Koritzinsky, M.; Wouters, B.G. PERK/eIF2 $\alpha$ signaling protects therapy resistant hypoxic cells through induction of glutathione synthesis and protection against ROS. Proc. Natl. Acad. Sci. USA 2013, 110, 4622-4627. [CrossRef]

164. Yoneda, A.; Minomi, K.; Tamura, Y. HSP47 promotes metastasis of breast cancer by interacting with myosin IIA via the unfolded protein response transducer IRE1 $\alpha$. Oncogene 2020, 39, 4519-4537. [CrossRef]

165. Chen, X.; Iliopoulos, D.; Zhang, Q.; Tang, Q.; Greenblatt, M.B.; Hatziapostolou, M.; Lim, E.; Tam, W.L.; Ni, M.; Chen, Y. XBP1 promotes triple-negative breast cancer by controlling the HIF1 $\alpha$ pathway. Nature 2014, 508, 103-107. [CrossRef]

166. Dong, H.; Adams, N.M.; Xu, Y.; Cao, J.; Allan, D.S.; Carlyle, J.R.; Chen, X.; Sun, J.C.; Glimcher, L.H. The IRE1 endoplasmic reticulum stress sensor activates natural killer cell immunity in part by regulating c-Myc. Nat. Immunol. 2019, 20, 865-878. [CrossRef] [PubMed]

167. Lee, B.-R.; Chang, S.-Y.; Hong, E.-H.; Kwon, B.-E.; Kim, H.M.; Kim, Y.-J.; Lee, J.; Cho, H.-J.; Cheon, J.-H.; Ko, H.-J. Elevated endoplasmic reticulum stress reinforced immunosuppression in the tumor microenvironment via myeloid-derived suppressor cells. Oncotarget 2014, 5, 12331. [CrossRef] [PubMed]

168. Sareddy, G.; Viswanadhapalli, S.; Surapaneni, P.; Suzuki, T.; Brenner, A.; Vadlamudi, R. Novel KDM1A inhibitors induce differentiation and apoptosis of glioma stem cells via unfolded protein response pathway. Oncogene 2017, 36, $2423-2434$. [CrossRef] [PubMed]

169. Köditz, J.; Nesper, J.; Wottawa, M.; Stiehl, D.P.; Camenisch, G.; Franke, C.; Myllyharju, J.; Wenger, R.H.; Katschinski, D.M. Oxygen-dependent ATF-4 stability is mediated by the PHD3 oxygen sensor. Blood J. Am. Soc. Hematol. 2007, 110, $3610-3617$. [CrossRef] [PubMed]

170. Kucharzewska, P.; Christianson, H.C.; Welch, J.E.; Svensson, K.J.; Fredlund, E.; Ringnér, M.; Mörgelin, M.; Bourseau-Guilmain, E.; Bengzon, J.; Belting, M. Exosomes reflect the hypoxic status of glioma cells and mediate hypoxia-dependent activation of vascular cells during tumor development. Proc. Natl. Acad. Sci. USA 2013, 110, 7312-7317. [CrossRef] [PubMed]

171. King, H.W.; Michael, M.Z.; Gleadle, J.M. Hypoxic enhancement of exosome release by breast cancer cells. BMC Cancer 2012, 12, 1-10. [CrossRef]

172. Panigrahi, G.K.; Praharaj, P.P.; Peak, T.C.; Long, J.; Singh, R.; Rhim, J.S.; Abd Elmageed, Z.Y.; Deep, G. Hypoxia-induced exosome secretion promotes survival of African-American and Caucasian prostate cancer cells. Sci. Rep. 2018, 8, 1-13.

173. Dorayappan, K.D.P.; Wanner, R.; Wallbillich, J.J.; Saini, U.; Zingarelli, R.; Suarez, A.A.; Cohn, D.E.; Selvendiran, K. Hypoxiainduced exosomes contribute to a more aggressive and chemoresistant ovarian cancer phenotype: A novel mechanism linking STAT3/Rab proteins. Oncogene 2018, 37, 3806-3821. [CrossRef]

174. Umezu, T.; Tadokoro, H.; Azuma, K.; Yoshizawa, S.; Ohyashiki, K.; Ohyashiki, J.H. Exosomal miR-135b shed from hypoxic multiple myeloma cells enhances angiogenesis by targeting factor-inhibiting HIF-1. Blood J. Am. Soc. Hematol. 2014, 124, $3748-3757$. [CrossRef]

175. Ramteke, A.; Ting, H.; Agarwal, C.; Mateen, S.; Somasagara, R.; Hussain, A.; Graner, M.; Frederick, B.; Agarwal, R.; Deep, G. Exosomes secreted under hypoxia enhance invasiveness and stemness of prostate cancer cells by targeting adherens junction molecules. Mol. Carcinog. 2015, 54, 554-565. [CrossRef] [PubMed]

176. Schlaepfer, I.R.; Nambiar, D.K.; Ramteke, A.; Kumar, R.; Dhar, D.; Agarwal, C.; Bergman, B.; Graner, M.; Maroni, P.; Singh, R.P. Hypoxia induces triglycerides accumulation in prostate cancer cells and extracellular vesicles supporting growth and invasiveness following reoxygenation. Oncotarget 2015, 6, 22836. [CrossRef]

177. Hwang, W.-L.; Lan, H.-Y.; Cheng, W.-C.; Huang, S.-C.; Yang, M.-H. Tumor stem-like cell-derived exosomal RNAs prime neutrophils for facilitating tumorigenesis of colon cancer. J. Hematol. Oncol. 2019, 12, 1-17. [CrossRef] [PubMed]

178. Wang, T.; Gilkes, D.M.; Takano, N.; Xiang, L.; Luo, W.; Bishop, C.J.; Chaturvedi, P.; Green, J.J.; Semenza, G.L. Hypoxia-inducible factors and RAB22A mediate formation of microvesicles that stimulate breast cancer invasion and metastasis. Proc. Natl. Acad. Sci. USA 2014, 111, E3234-E3242. [CrossRef] [PubMed]

179. Zhang, W.; Zhou, X.; Yao, Q.; Liu, Y.; Zhang, H.; Dong, Z. HIF-1-mediated production of exosomes during hypoxia is protective in renal tubular cells. Am. J. Physiol. Ren. Physiol. 2017, 313, F906-F913. [CrossRef] [PubMed] 
180. Zhao, J.; Zhang, J.; Yu, M.; Xie, Y.; Huang, Y.; Wolff, D.W.; Abel, P.W.; Tu, Y. Mitochondrial dynamics regulates migration and invasion of breast cancer cells. Oncogene 2013, 32, 4814-4824. [CrossRef]

181. Han, X.-J.; Yang, Z.-J.; Jiang, L.-P.; Wei, Y.-F.; Liao, M.-F.; Qian, Y.; Li, Y.; Huang, X.; Wang, J.-B.; Xin, H.-B. Mitochondrial dynamics regulates hypoxia-induced migration and antineoplastic activity of cisplatin in breast cancer cells. Int. J. Oncol. 2015, 46, 691-700. [CrossRef] [PubMed]

182. Peiris-Pagès, M.; Bonuccelli, G.; Sotgia, F.; Lisanti, M.P. Mitochondrial fission as a driver of stemness in tumor cells: mDIVI1 inhibits mitochondrial function, cell migration and cancer stem cell (CSC) signalling. Oncotarget 2018, 9, 13254. [CrossRef]

183. Zhang, J.; Wang, C.; Chen, X.; Takada, M.; Fan, C.; Zheng, X.; Wen, H.; Liu, Y.; Wang, C.; Pestell, R.G.; et al. EglN2 associates with the NRF1-PGC1alpha complex and controls mitochondrial function in breast cancer. EMBO J. 2015, 34, 2953-2970. [CrossRef]

184. Bao, M.H.-R.; Yang, C.; Tse, A.P.-W.; Wei, L.; Lee, D.; Zhang, M.S.; Goh, C.C.; Chiu, D.K.-C.; Yuen, V.W.-H.; Law, C.-T. Genomewide CRISPR-Cas9 knockout library screening identified PTPMT1 in cardiolipin synthesis is crucial to survival in hypoxia in liver cancer. Cell Rep. 2021, 34, 108676. [CrossRef] [PubMed]

185. Scharping, N.E.; Rivadeneira, D.B.; Menk, A.V.; Vignali, P.D.; Ford, B.R.; Rittenhouse, N.L.; Peralta, R.; Wang, Y.; Wang, Y.; DePeaux, K. Mitochondrial stress induced by continuous stimulation under hypoxia rapidly drives $\mathrm{T}$ cell exhaustion. Nat. Immunol. 2021, 22, 205-215. [CrossRef]

186. Tang, T.; Yang, Z.; Zhu, Q.; Wu, Y.; Sun, K.; Alahdal, M.; Zhang, Y.; Xing, Y.; Shen, Y.; Xia, T. Up-regulation of miR-210 induced by a hypoxic microenvironment promotes breast cancer stem cell metastasis, proliferation, and self-renewal by targeting E-cadherin. FASEB J. 2018, 32, 6965-6981. [CrossRef] [PubMed]

187. Gasparini, P.; Lovat, F.; Fassan, M.; Casadei, L.; Cascione, L.; Jacob, N.K.; Carasi, S.; Palmieri, D.; Costinean, S.; Shapiro, C.L. Protective role of miR-155 in breast cancer through RAD51 targeting impairs homologous recombination after irradiation. Proc. Natl. Acad. Sci. USA 2014, 111, 4536-4541. [CrossRef] [PubMed]

188. Mansoori, B.; Mohammadi, A.; Davudian, S.; Shirjang, S.; Baradaran, B. The different mechanisms of cancer drug resistance: A brief review. Adv. Pharm. Bull. 2017, 7, 339. [CrossRef]

189. Lin, C.; Yang, L. Long noncoding RNA in cancer: Wiring signaling circuitry. Trends Cell Biol. 2018, 28, 287-301. [CrossRef]

190. Zhou, X.; Liu, S.; Cai, G.; Kong, L.; Zhang, T.; Ren, Y.; Wu, Y.; Mei, M.; Zhang, L.; Wang, X. Long non coding RNA MALAT1 promotes tumor growth and metastasis by inducing epithelial-mesenchymal transition in oral squamous cell carcinoma. Sci. Rep. 2015, 5, 15972. [CrossRef]

191. Shih, J.-W.; Chiang, W.-F.; Wu, A.T.; Wu, M.-H.; Wang, L.-Y.; Yu, Y.-L.; Hung, Y.-W.; Wang, W.-C.; Chu, C.-Y.; Hung, C.-L. Long noncoding RNA LncHIFCAR/MIR31HG is a HIF-1 $\alpha$ co-activator driving oral cancer progression. Nat. Commun. 2017, 8, 1-16. [CrossRef]

192. Zhu, G.; Wang, S.; Chen, J.; Wang, Z.; Liang, X.; Wang, X.; Jiang, J.; Lang, J.; Li, L. Long noncoding RNA HAS2-AS1 mediates hypoxia-induced invasiveness of oral squamous cell carcinoma. Mol. Carcinog. 2017, 56, 2210-2222. [CrossRef]

193. Niu, Y.; Bao, L.; Chen, Y.; Wang, C.; Luo, M.; Zhang, B.; Zhou, M.; Wang, J.E.; Fang, Y.V.; Kumar, A. HIF2-induced long noncoding RNA RAB11B-AS1 promotes hypoxia-mediated angiogenesis and breast cancer metastasis. Cancer Res. 2020, 80, 964-975. [CrossRef]

194. Jin, Y.; Che, X.; Qu, X.; Li, X.; Lu, W.; Wu, J.; Wang, Y.; Hou, K.; Li, C.; Zhang, X. CircHIPK3 promotes metastasis of gastric cancer via miR-653-5p/miR-338-3p-NRP1 axis under a long-term hypoxic microenvironment. Front. Oncol. 2020, 10, 1612. [CrossRef] [PubMed]

195. Buurman, R.; Gürlevik, E.; Schäffer, V.; Eilers, M.; Sandbothe, M.; Kreipe, H.; Wilkens, L.; Schlegelberger, B.; Kühnel, F.; Skawran, B. Histone deacetylases activate hepatocyte growth factor signaling by repressing microRNA-449 in hepatocellular carcinoma cells. Gastroenterology 2012, 143, 811-820.e815. [CrossRef]

196. Hsieh, Y.-L.; Tu, H.-J.; Pan, S.-L.; Liou, J.-P.; Yang, C.-R. Anti-metastatic activity of MPT0G211, a novel HDAC6 inhibitor, in human breast cancer cells in vitro and in vivo. Biochim. Biophys. Acta Mol. Cell Res. 2019, 1866, 992-1003. [CrossRef]

197. Dong, J.; Zheng, N.; Wang, X.; Tang, C.; Yan, P.; Zhou, H.-B.; Huang, J. A novel HDAC6 inhibitor exerts an anti-cancer effect by triggering cell cycle arrest and apoptosis in gastric cancer. Eur. J. Pharmacol. 2018, 828, 67-79. [CrossRef] [PubMed]

198. Dowling, C.M.; Hollinshead, K.E.; Di Grande, A.; Pritchard, J.; Zhang, H.; Dillon, E.T.; Haley, K.; Papadopoulos, E.; Mehta, A.K.; Bleach, R. Multiple screening approaches reveal HDAC6 as a novel regulator of glycolytic metabolism in triple-negative breast cancer. Sci. Adv. 2021, 7, eabc4897. [CrossRef]

199. Daskalaki, I.; Gkikas, I.; Tavernarakis, N. Hypoxia and selective autophagy in cancer development and therapy. Front. Cell Dev. Biol. 2018, 6, 104. [CrossRef] [PubMed]

200. Noman, M.Z.; Janji, B.; Kaminska, B.; Van Moer, K.; Pierson, S.; Przanowski, P.; Buart, S.; Berchem, G.; Romero, P.; Mami-Chouaib, F. Blocking hypoxia-induced autophagy in tumors restores cytotoxic T-cell activity and promotes regression. Cancer Res. 2011, 71, 5976-5986. [CrossRef]

201. Baginska, J.; Viry, E.; Berchem, G.; Poli, A.; Noman, M.Z.; van Moer, K.; Medves, S.; Zimmer, J.; Oudin, A.; Niclou, S.P. Granzyme B degradation by autophagy decreases tumor cell susceptibility to natural killer-mediated lysis under hypoxia. Proc. Natl. Acad. Sci. USA 2013, 110, 17450-17455. [CrossRef]

202. Song, X.; Feng, L.; Liang, C.; Yang, K.; Liu, Z. Ultrasound triggered tumor oxygenation with oxygen-shuttle nanoperfluorocarbon to overcome hypoxia-associated resistance in cancer therapies. Nano Lett. 2016, 16, 6145-6153. [CrossRef] [PubMed] 
203. Lin, A.J.; Cosby, L.A.; Shansky, C.W.; Sartorelli, A.C. Potential bioreductive alkylating agents. 1. Benzoquinone derivatives. J. Med. Chem. 1972, 15, 1247-1252. [CrossRef]

204. Williams, K.J.; Cowen, R.L.; Stratford, I.J. Hypoxia and oxidative stress in breast cancer Tumour hypoxia-therapeutic considerations. Breast Cancer Res. 2001, 3, 1-4. [CrossRef] [PubMed]

205. Wilson, W.R.; Hay, M.P. Targeting hypoxia in cancer therapy. Nat. Rev. Cancer 2011, 11, 393-410. [CrossRef]

206. Sun, J.D.; Liu, Q.; Wang, J.; Ahluwalia, D.; Ferraro, D.; Wang, Y.; Duan, J.-X.; Ammons, W.S.; Curd, J.G.; Matteucci, M.D. Selective tumor hypoxia targeting by hypoxia-activated prodrug TH-302 inhibits tumor growth in preclinical models of cancer. Clin. Cancer Res. 2012, 18, 758-770. [CrossRef] [PubMed]

207. Mistry, I.N.; Thomas, M.; Calder, E.D.; Conway, S.J.; Hammond, E.M. Clinical advances of hypoxia-activated prodrugs in combination with radiation therapy. Int. J. Radiat. Oncol. Biol. Phys. 2017, 98, 1183-1196. [CrossRef] [PubMed]

208. Spiegelberg, L.; Houben, R.; Niemans, R.; de Ruysscher, D.; Yaromina, A.; Theys, J.; Guise, C.P.; Smaill, J.B.; Patterson, A.V.; Lambin, P. Hypoxia-activated prodrugs and (lack of) clinical progress: The need for hypoxia-based biomarker patient selection in phase III clinical trials. Clin. Transl. Radiat. Oncol. 2019, 15, 62-69. [CrossRef] [PubMed]

209. Fallah, J.; Rini, B.I. HIF inhibitors: Status of current clinical development. Curr. Oncol. Rep. 2019, 21, 6. [CrossRef]

210. Xu, R.; Wang, K.; Rizzi, J.P.; Huang, H.; Grina, J.A.; Schlachter, S.T.; Wang, B.; Wehn, P.M.; Yang, H.; Dixon, D.D. $3-[(1$ S, 2 S, 3 R)-2, 3-Difluoro-1-hydroxy-7-methylsulfonylindan-4-yl] oxy-5-fluorobenzonitrile (PT2977), a hypoxia-inducible factor 2 $\alpha$ (HIF-2 $\alpha$ ) inhibitor for the treatment of clear cell Renal cell carcinoma. J. Med. Chem. 2019, 62, 6876-6893. [CrossRef]

211. Courtney, K.D.; Ma, Y.; de Leon, A.D.; Christie, A.; Xie, Z.; Woolford, L.; Singla, N.; Joyce, A.; Hill, H.; Madhuranthakam, A.J. HIF-2 complex dissociation, target inhibition, and acquired resistance with PT2385, a first-in-class HIF-2 inhibitor, in patients with clear cell renal cell carcinoma. Clin. Cancer Res. 2020, 26, 793-803. [CrossRef]

212. Kioi, M.; Vogel, H.; Schultz, G.; Hoffman, R.M.; Harsh, G.R.; Brown, J.M. Inhibition of vasculogenesis, but not angiogenesis, prevents the recurrence of glioblastoma after irradiation in mice. J. Clin. Investig. 2010, 120, 694-705. [CrossRef]

213. Hu, H.; Miao, X.-K.; Li, J.-Y.; Zhang, X.-W.; Xu, J.-J.; Zhang, J.-Y.; Zhou, T.-X.; Hu, M.-N.; Yang, W.-L.; Mou, L.-Y. YC-1 potentiates the antitumor activity of gefitinib by inhibiting HIF-1 $\alpha$ and promoting the endocytic trafficking and degradation of EGFR in gefitinib-resistant non-small-cell lung cancer cells. Eur. J. Pharmacol. 2020, 874, 172961. [CrossRef]

214. Wu, S.-L.; Li, Y.-J.; Liao, K.; Shi, L.; Zhang, N.; Liu, S.; Hu, Y.-Y.; Li, S.-L.; Wang, Y. 2-Methoxyestradiol inhibits the proliferation and migration and reduces the radioresistance of nasopharyngeal carcinoma CNE-2 stem cells via NF- $\mathrm{kB} / \mathrm{HIF}-1$ signaling pathway inactivation and EMT reversal. Oncol. Rep. 2017, 37, 793-802. [CrossRef] [PubMed]

215. Pang, Y.; Yang, C.; Schovanek, J.; Wang, H.; Bullova, P.; Caisova, V.; Gupta, G.; Wolf, K.I.; Semenza, G.L.; Zhuang, Z. Anthracyclines suppress pheochromocytoma cell characteristics, including metastasis, through inhibition of the hypoxia signaling pathway. Oncotarget 2017, 8, 22313. [CrossRef] [PubMed]

216. Hong, K.; Hu, L.; Liu, X.; Simon, J.M.; Ptacek, T.S.; Zheng, X.; Liao, C.; Baldwin, A.S.; Zhang, Q. USP37 promotes deubiquitination of HIF $2 \alpha$ in kidney cancer. Proc. Natl. Acad. Sci. USA 2020, 117, 13023-13032. [CrossRef] [PubMed]

217. Lachenmayer, A.; Toffanin, S.; Cabellos, L.; Alsinet, C.; Hoshida, Y.; Villanueva, A.; Minguez, B.; Tsai, H.-W.; Ward, S.C.; Thung, S. Combination therapy for hepatocellular carcinoma: Additive preclinical efficacy of the HDAC inhibitor panobinostat with sorafenib. J. Hepatol. 2012, 56, 1343-1350. [CrossRef]

218. Jin, N.; Lubner, S.J.; Mulkerin, D.L.; Rajguru, S.; Carmichael, L.; Chenv, H.; Holen, K.D.; LoConte, N.K. A phase II trial of a histone deacetylase inhibitor panobinostat in patients with low-grade neuroendocrine tumors. Oncologist 2016, 21, 785. [CrossRef]

219. Liao, C.; Zhang, Y.; Fan, C.; Herring, L.E.; Liu, J.; Locasale, J.W.; Takada, M.; Zhou, J.; Zurlo, G.; Hu, L. Identification of BBOX1 as a therapeutic target in triple-negative breast cancer. Cancer Discov. 2020, 10, 1706-1721. [CrossRef] [PubMed]

220. Holdstock, L.; Meadowcroft, A.M.; Maier, R.; Johnson, B.M.; Jones, D.; Rastogi, A.; Zeig, S.; Lepore, J.J.; Cobitz, A.R. Four-week studies of oral hypoxia-inducible factor-prolyl hydroxylase inhibitor GSK1278863 for treatment of anemia. J. Am. Soc. Nephrol. 2016, 27, 1234-1244. [CrossRef]

221. Eltzschig, H.K.; Bratton, D.L.; Colgan, S.P. Targeting hypoxia signalling for the treatment of ischaemic and inflammatory diseases. Nat. Rev. Drug Discov. 2014, 13, 852-869. [CrossRef]

222. Si, Y.; Liu, J.; Shen, H.; Zhang, C.; Wu, Y.; Huang, Y.; Gong, Z.; Xue, J.; Liu, T. Fisetin decreases TET 1 activity and CCNY/CDK 16 promoter $5 \mathrm{hmC}$ levels to inhibit the proliferation and invasion of renal cancer stem cell. J. Cell. Mol. Med. 2019, 23, 1095-1105. [CrossRef]

223. Miyake, Y.; Itoh, Y.; Hatanaka, A.; Suzuma, Y.; Suzuki, M.; Kodama, H.; Arai, Y.; Suzuki, T. Identification of novel lysine demethylase 5-selective inhibitors by inhibitor-based fragment merging strategy. Bioorg. Med. Chem. 2019, 27, 1119-1129. [CrossRef]

224. Ye, Q.; Holowatyj, A.; Wu, J.; Liu, H.; Zhang, L.; Suzuki, T.; Yang, Z.-Q. Genetic alterations of KDM4 subfamily and therapeutic effect of novel demethylase inhibitor in breast cancer. Am. J. Cancer Res. 2015, 5, 1519.

225. Hoyle, R.G.; Wang, H.; Cen, Y.; Zhang, Y.; Li, J. IOX1 Suppresses Wnt Target Gene Transcription and Colorectal Cancer Tumorigenesis through Inhibition of KDM3 Histone Demethylases. Mol. Cancer Ther. 2021, 20, 191-202. [CrossRef]

226. Hu, Q.; Chen, J.; Zhang, J.; Xu, C.; Yang, S.; Jiang, H. IOX1, a JMJD2A inhibitor, suppresses the proliferation and migration of vascular smooth muscle cells induced by angiotensin II by regulating the expression of cell cycle-related proteins. Int. J. Mol. Med. 2016, 37, 189-196. [CrossRef] [PubMed] 
227. Mohammad, H.P.; Smitheman, K.N.; Kamat, C.D.; Soong, D.; Federowicz, K.E.; Van Aller, G.S.; Schneck, J.L.; Carson, J.D.; Liu, Y.; Butticello, M. A DNA hypomethylation signature predicts antitumor activity of LSD1 inhibitors in SCLC. Cancer Cell 2015, 28, 57-69. [CrossRef] [PubMed]

228. Huang, Y.; Su, R.; Sheng, Y.; Dong, L.; Dong, Z.; Xu, H.; Ni, T.; Zhang, Z.S.; Zhang, T.; Li, C. Small-molecule targeting of oncogenic FTO demethylase in acute myeloid leukemia. Cancer Cell 2019, 35, 677-691.e610. [CrossRef] [PubMed]

229. Ueda, M.; Shimizu, T.; Mabuchi, M.; Horiike, K.; Kitae, K.; Hase, H.; Ueda, Y.; Tsujikawa, K.; Tanaka, A. Novel metabolically stable PCA-1/ALKBH3 inhibitor has potent antiproliferative effects on DU145 cells in vivo. Anticancer. Res. 2018, 38, $211-218$.

230. Nigam, R.; Babu, K.R.; Ghosh, T.; Kumari, B.; Akula, D.; Rath, S.N.; Das, P.; Anindya, R.; Khan, F.A. Indenone derivatives as inhibitor of human DNA dealkylation repair enzyme AlkBH3. Bioorg. Med. Chem. 2018, 26, 4100-4112. [CrossRef] [PubMed]

231. Hu, L.; Xie, H.; Liu, X.; Potjewyd, F.; James, L.I.; Wilkerson, E.M.; Herring, L.E.; Xie, L.; Chen, X.; Cabrera, J.C. TBK1 is a synthetic lethal target in cancer with VHL loss. Cancer Discov. 2020, 10, 460-475. [CrossRef]

232. Jenkins, R.W.; Aref, A.R.; Lizotte, P.H.; Ivanova, E.; Stinson, S.; Zhou, C.W.; Bowden, M.; Deng, J.; Liu, H.; Miao, D. Ex vivo profiling of PD-1 blockade using organotypic tumor spheroids. Cancer Discov. 2018, 8, 196-215. [CrossRef] [PubMed]

233. Chan, N.; Pires, I.M.; Bencokova, Z.; Coackley, C.; Luoto, K.R.; Bhogal, N.; Lakshman, M.; Gottipati, P.; Oliver, F.J.; Helleday, T. Contextual synthetic lethality of cancer cell kill based on the tumor microenvironment. Cancer Res. 2010, 70, 8045-8054. [CrossRef] [PubMed]

234. Jayaprakash, P.; Ai, M.; Liu, A.; Budhani, P.; Bartkowiak, T.; Sheng, J.; Ager, C.; Nicholas, C.; Jaiswal, A.R.; Sun, Y. Targeted hypoxia reduction restores $\mathrm{T}$ cell infiltration and sensitizes prostate cancer to immunotherapy. J. Clin. Investig. 2018, 128, 5137-5149. [CrossRef] [PubMed]

235. Zhou, T.; Liang, X.; Wang, P.; Hu, Y.; Qi, Y.; Jin, Y.; Du, Y.; Fang, C.; Tian, J. A Hepatocellular Carcinoma Targeting Nanostrategy with Hypoxia-Ameliorating and Photothermal Abilities that, Combined with Immunotherapy, Inhibits Metastasis and Recurrence. ACS Nano 2020, 14, 12679-12696. [CrossRef]

236. Fong, L.; Hotson, A.; Powderly, J.D.; Sznol, M.; Heist, R.S.; Choueiri, T.K.; George, S.; Hughes, B.G.; Hellmann, M.D.; Shepard, D.R. Adenosine 2A receptor blockade as an immunotherapy for treatment-refractory renal cell cancer. Cancer Discov. 2020, 10, 40-53. [CrossRef] [PubMed]

237. Halpin-Veszeleiova, K.; Hatfield, S.M. Oxygenation and A2AR blockade to eliminate hypoxia/HIF-1 $\alpha$-adenosinergic immunosuppressive axis and improve cancer immunotherapy. Curr. Opin. Pharmacol. 2020, 53, 84-90. [CrossRef]

238. Schafer, Z.T.; Grassian, A.R.; Song, L.; Jiang, Z.; Gerhart-Hines, Z.; Irie, H.Y.; Gao, S.; Puigserver, P.; Brugge, J.S. Antioxidant and oncogene rescue of metabolic defects caused by loss of matrix attachment. Nature 2009, 461, 109-113. [CrossRef]

239. Piskounova, E.; Agathocleous, M.; Murphy, M.M.; Hu, Z.; Huddlestun, S.E.; Zhao, Z.; Leitch, A.M.; Johnson, T.M.; DeBerardinis, R.J.; Morrison, S.J. Oxidative stress inhibits distant metastasis by human melanoma cells. Nature 2015, 527, 186-191. [CrossRef]

240. Uribesalgo, I.; Hoffmann, D.; Zhang, Y.; Kavirayani, A.; Lazovic, J.; Berta, J.; Novatchkova, M.; Pai, T.P.; Wimmer, R.A.; László, V. Apelin inhibition prevents resistance and metastasis associated with anti-angiogenic therapy. EMBO Mol. Med. 2019, 11, e9266. [CrossRef]

241. Maione, F.; Capano, S.; Regano, D.; Zentilin, L.; Giacca, M.; Casanovas, O.; Bussolino, F.; Serini, G.; Giraudo, E. Semaphorin 3A overcomes cancer hypoxia and metastatic dissemination induced by antiangiogenic treatment in mice. J. Clin. Investig. 2012, 122, 1832-1848. [CrossRef] 